\title{
Strong Earthquake Sequences in Greece during 2008-2014: Moment Tensor Inversions and Fault Plane Discrimination
}

\author{
Alexandra Moshou \\ Institute of Geodynamics, National Observatory of Athens, Athens, Greece \\ Email:amoshou@noa.gr
}

How to cite this paper: Moshou, A. (2020) Strong Earthquake Sequences in Greece during 2008-2014: Moment Tensor Inversions and Fault Plane Discrimination. Open Journal of Earthquake Research, 9, 323-348. https://doi.org/10.4236/ojer.2020.94019

Received: May 1, 2020

Accepted: July 31, 2020

Published: August 3, 2020

Copyright $\odot 2020$ by author(s) and Scientific Research Publishing Inc. This work is licensed under the Creative Commons Attribution International License (CC BY 4.0).

http://creativecommons.org/licenses/by/4.0/

\section{(c) (i) Open Access}

\begin{abstract}
As is well known, Greece has a significant number of earthquakes each year. In recent years, several earthquakes have occurred in Greece. For this scope, a methodology was used to determine the source parameters. This methodology is based on minimizing the difference between the observed and the synthetic waveforms, using the method Source Parameters Calculation-SPCa [1]. The source parameters, using the proposed methodology, are calculated by comparing observed seismograms and synthetic by inverting data. The synthetics are calculated using the reflectivity method (Kennett, 1983) as implemented by Randall et al. (1994) for a given earth structure. This study includes inversion results for the strongest events that occurred in Greece from 2008 to 2014. For the same events calculated the main fault plane, using the method of Hypocenter Centroid-plot (HC-plot) [2] [3]. This methodology is a simple geometrical method based on the combination between the hypocentral position and the two possible fault planes.
\end{abstract}

\section{Keywords}

Synthetic Seismograms, Moment Tensor Inversion, Focal Mechanism, Regional Data, Nodal Planes

\section{Introduction}

The seismic moment tensor constitutes the most important source parameter since it describes in a first-order approximation the equivalent forces applied on a fault plane and can be calculated by body wave modeling. The moment tensor as a mathematical description of equivalent forces and moments is used to study the source processes. The propagation and the source effects characterize varia- 
tions of the observed seismograms. Mathematically, each one of these effects can be calculated to generate synthetic seismograms that can be compared directly to the corresponding observed ones. The best solution is obtained by the minimization of the difference between the observed and the synthetic seismograms (Aki and Richards, 1980).

General a seismic source can be representing by a symmetric square matrix ( 3 $\times 3$ ) with 6 independent elements. Eigenvalue and eigenvector analysis of the moment tensor can be used to determine the components of the moment tensor. All the mathematical expressions described analytically in the studies [4] [5].

The linear dipole is compensated by two other linear dipoles along with the other two perpendicular directions. The eigenvalues describe the isotropic component of the moment tensor. In the case that the sum of the eigenvalues is vanished the applied forces constitute a pure double couple source. In this case, the seismic moment tensor has only deviatoric components [5] [6]. In general, a complete moment tensor is the superposition of the two vector dipoles (DC and CLVD) and isotropic component [5] [6]. In the case of an earthquake, the isotropic part is zero.

\section{Applied Methodology and Preparation of Data}

Seismological digital broadband data from the Hellenic Unified Seismological Network (HUSN) were collected and analyzed to calculate the source parameters of the strongest earthquakes that occurred in the Greece area, for the last six years. For this purpose, a methodology based on a moment tensor inversion was used, using the software of Ammon [7]. This method calculates synthetic seismograms directly compared with the observed ones for a given velocity structure. The reflectivity method of Kennett [8] as implemented by Randall [9] was applied to determine the Green Functions, initially calculated for different depths by the analyst. Iterative inversions were performed at depth intervals of $5 \mathrm{~km}$ followed by a finer one of $1-2 \mathrm{~km}$ steps around the depth exhibiting the lowest misfit.

Regional data at least five broadband stations, at different azimuthal coverage and epicentral distances less than $3^{\circ}$, equipped with three components seismometers, were selected and analyzed. The preparation of the data, includes the deconvolution of instrument response, following the velocity was integrated to displacement and finally, the horizontal components rotated to radial and transverse ones. Then the method uses the long period part of the signal to invert.

A bandpass filter is applied both on the observed waveforms and synthetics, having a fixed length of $70 \mathrm{sec}$. The inversion results indicate that inverting waveforms longer than $70 \mathrm{sec}$ resulted in higher misfits. The quality of the results of moment tensor solutions can be evaluated by considering the average misfit and the compensated linear vector dipole (CLVD). For each solution, there is a quality code that consists of the letters $\mathrm{A}-\mathrm{D}$, for the minimum misfit 
and between the numbers 1 - 4 for the percent of CLVD [9].

Finally, for all the previous events we determined the main fault plane that activated, using the Hypocenter Centroid-plot (HC-plot). In this methodology is putting hypocenter and centroid of the 3 components local waveform inversion is located in three-dimensional space, and later calculate its distance to both faulting planes. If the hypocenter is located on one of the two plane faults, so the fault plane is the real fault plane. If the hypocenter is not located in one of the two-fault planes the real fault plane is the closest one to the hypo-center [2] [3].

\section{Applications}

The proposed methodology was applied to the largest earthquakes that occurred recently in Greece. The first two applications concern the 2006 Kythira and the 2008 Leonidio earthquakes (deep events), while the last five concern the seismic sequences that occurred in Greece last year.

On February 2008, three strong events $(\mathrm{Mw}=6.7,6.1$ and 6.0) occurred South of Methoni, at a segment of the Hellenic arc which was not activated during the instrumental period. This sequence was followed by a large number of aftershocks, the strongest of which were processed to calculate their source parameters. On the other hand, the aftershock distribution of the 2008 Andravida (Mw $=6.4$ ) earthquake extended to an area significantly larger than the one expected according to the magnitude of the main event. Also, the source parameters for the three seismic sequences in Limnos Island (08/01/2013), in Kallidromon Mountain (Central Greece, 07/08/2013) and finally the most recent in Kefallinia Island (26/01/2014) were calculated. The obtained source parameters were compared to the seismotectonic characteristics of each seismogenic area. These events occurred in different seismotectonic settings, the fact that permits us to evaluate the reliability of the method.

\subsection{The $M w=6.6,2006$ Kythira Earthquake}

On 8 January 2006 (11:34 GMT) an earthquake of Magnitude Mw $=6.6$ occurred close to the Northeast coast of Kythira Island (Southern Greece) causing some damages landslides and rockfalls. The hypocenter as estimated by the National Observatory of Athens, http://bbnet.gein.noa.gr/alerts manual/2006/01/evman060108113454 info.html was calculated $36.214^{\circ} \mathrm{N}, 23.406^{\circ} \mathrm{E}$, and the focal depth at $69 \mathrm{Km}$. This event is located in the Hellenic subduction zone which characterizes the Southern part of Greece. The shock was felt in a spatially extended area that covered Greece, Italy, Turkey, Egypt, Cyprus, Israel, Syria, Jordan, and Lebanon. This event is one of the largest earthquakes, after the event of $1903(\mathrm{M}=7.3)$, which occurred in the same area. Previous works indicate the existence of a seismic gap in this region [10]. The major part of the seismic activity in this region is related to the active subduction zone along the Hellenic Arc, as well as the backarc area. Consequently, the area presents complex deformation, where the southern part of the 
Aegean region is moving towards the southwest at approximately $40 \mathrm{~mm} / \mathrm{yr}$ [11] [12]. The area is characterized by active normal faults (Danamos, 1992) with an almost vertical orientation concerning the subduction zone. The main event was followed by a small number of aftershocks, as it appeared in Figure 1 .

Thrust type faulting was revealed after applying moment tensor inversion. The obtained focal mechanism is strike $=205^{\circ}$, dip $=48^{\circ}$ and rake $=59^{\circ}$ with a seismic moment equal to $8.4 \times 10^{25} \mathrm{dyn} \cdot \mathrm{cm}$, and a focal depth equal to $65 \mathrm{~km}$ (Figure 2).

The obtained focal mechanism calculated using data in regional distances is in agreement with the one proposed by the Harvard CMT solution, using teleseismic data.

Using manually locations of HRV, NOA and UOA and their respectively Moment Tensors (Table 1) with the varied depth we obtain $\mathrm{H}-\mathrm{C}$ consistent solution.

The fault plane is the nodal plane with strike $=205^{\circ}$, dip $=48^{\circ}$ and strike $=$ $59^{\circ}$. The distance of the hypocenter from this plane is $7.5 \mathrm{~km}$, while the distance from the other plane is $22.30 \mathrm{~km}$. The distance between Hypocenter and Centroid is $33 \mathrm{~km}$ (Figure 3 ).

\subsection{The Mw $=6.0,2008$ Leonidio Earthquake}

On January 6, 2008 (05:14, UTC) a strong earthquake happened near the Leonidio

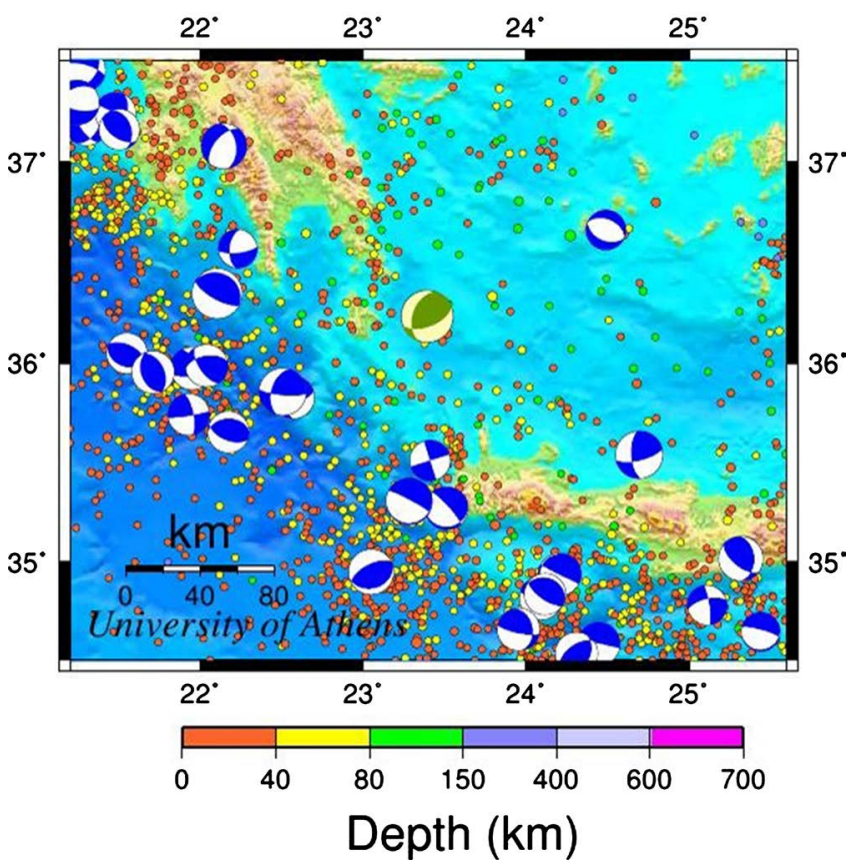

Figure 1. Hypocenter of aftershocks detected and localized using data from Geofon network, for the time interval 1990-2006 is shown by oranges, yellow and green circles respectively to the depth scale. The focal mechanism of the main event is represented by a green beach ball while blue color appears all the other focal mechanisms in the same region, http://www.geophysics.geol.uoa.gr/imageseis/eqs/2006/20060108 kyth/earthquake large en.html\#meca. 

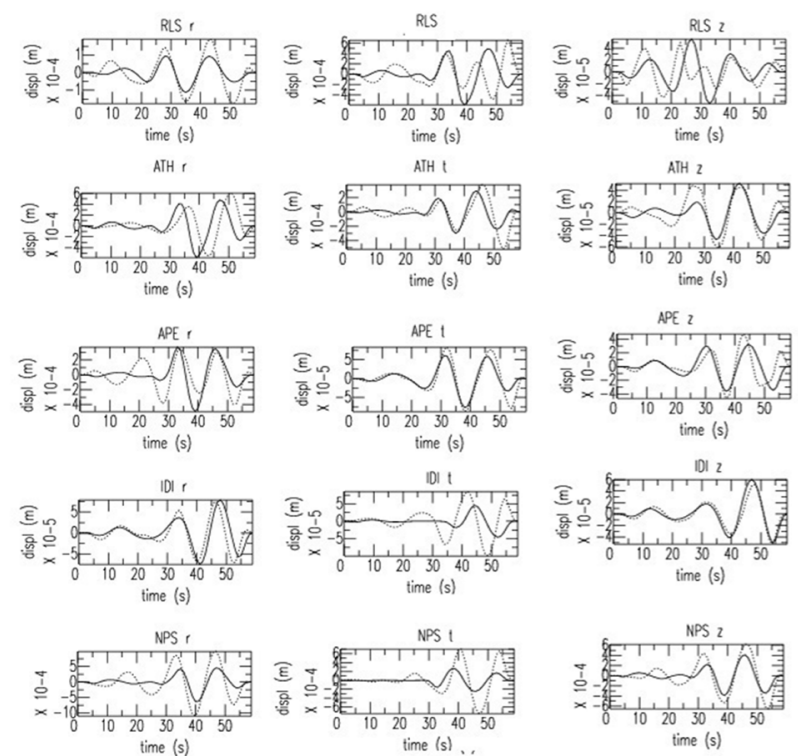
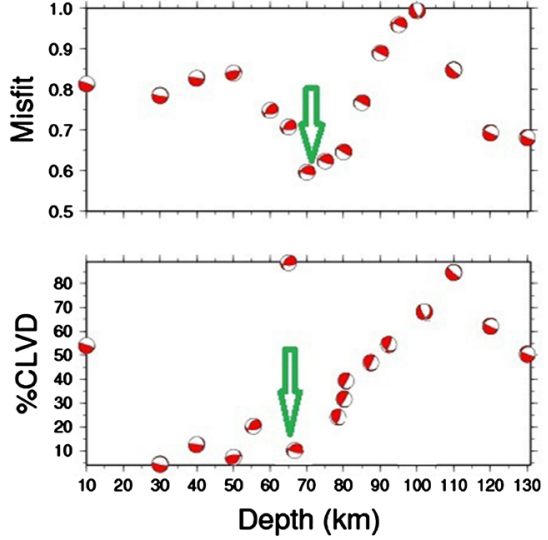

Latitude: $36.214^{\circ} \mathrm{N}$ Longitude: $23.406^{\circ} \mathrm{E}$ Time: 2006/01/08 11:34:54.0

\section{Depth $=69 \mathrm{~km}$ \\ $\mathrm{M}_{\mathrm{w}}=6.6$ \\ $\mathrm{M}_{0}=9.100 \mathrm{E}+25 \mathrm{dyn} * \mathrm{~cm}$}

$$
\begin{aligned}
& \text { Plane 1: } \\
& \text { Strike }\left(^{\circ}\right)=205 \\
& \text { Dip }\left({ }^{\circ}\right)=48 \\
& \text { Rake }\left(^{\circ}\right)=59 \\
& \text { Plane 2: } \\
& \text { Strike }\left(^{\circ}\right)=67 \\
& \text { Dip }\left(^{\circ}\right)=50 \\
& \text { Rake }\left(^{\circ}\right)=120 \\
& \text { Misfit }=0.55 \\
& \text { CLVD }(\%)=10
\end{aligned}
$$

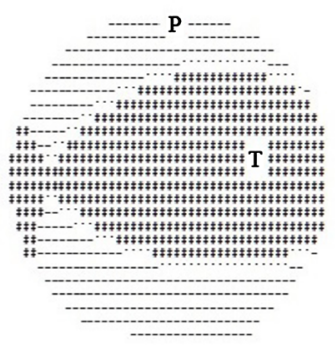

Quality: B1

Stations Used: RLS, ATH, APE, IDI, NPS

Computed by: A. Moshou

Figure 2. Moment tensor solution of the 8 January 2006 (11:34 GMT) earthquake. The selected solution is highlighted with the green arrow in the misfit/CLVD-versus-depth diagrams. Down of this are appeared the summary of the solution and the corresponding beach ball. To the left of misfit/CLVD diagrams observed and synthetic displacement waveforms (continuous and dotted lines respectively) are shown, at the inverted stations for the radial, tangential and vertical components. At the lower part of the figure the summary of the solution and the fault plane solution as lower hemisphere equal-area projection, are depicted.

Table 1. Manual Locations and focal mechanisms by various agencies, Sources: HARV, UOA solution.

\begin{tabular}{ccccccccccc}
\hline Agency & Lat $\left({ }^{\circ}\right)$ & Lon $\left(^{\circ}\right)$ & Depth $(\mathrm{km})$ & $\mathbf{M}_{\mathrm{w}}$ & Strike 1 $\left(^{\circ}\right)$ & Dip 1 $\left(^{\circ}\right)$ & Rake 1 $\left(^{\circ}\right)$ & Strike 2 $\left(^{\circ}\right)$ & Dip 2 $\left(^{\circ}\right)$ & Rake 2 $\left.^{\circ}\right)$ \\
\hline This study & 36.21 & 23.40 & 69 & 6.6 & 205 & 48 & 59 & 67 & 50 & 120 \\
HARV & 35.93 & 23.29 & 64 & 6.7 & 201 & 44 & 55 & 66 & 55 & 119 \\
UOA & 36.23 & 23.39 & 65 & 6.6 & 210 & 36 & 50 & 76 & 63 & 115 \\
\hline
\end{tabular}

town, Southern Peloponnesus. The geographical coordinates, as they calculated by National Observatory of Athens found, $37.114^{\circ} \mathrm{N}, 22.775^{\circ} \mathrm{E}$ and the depth at $86 \mathrm{~km}$. There were no injuries or damages reported. The main event was followed by a small number of aftershocks since it is an intermediate-depth earthquake (Figure 4). 

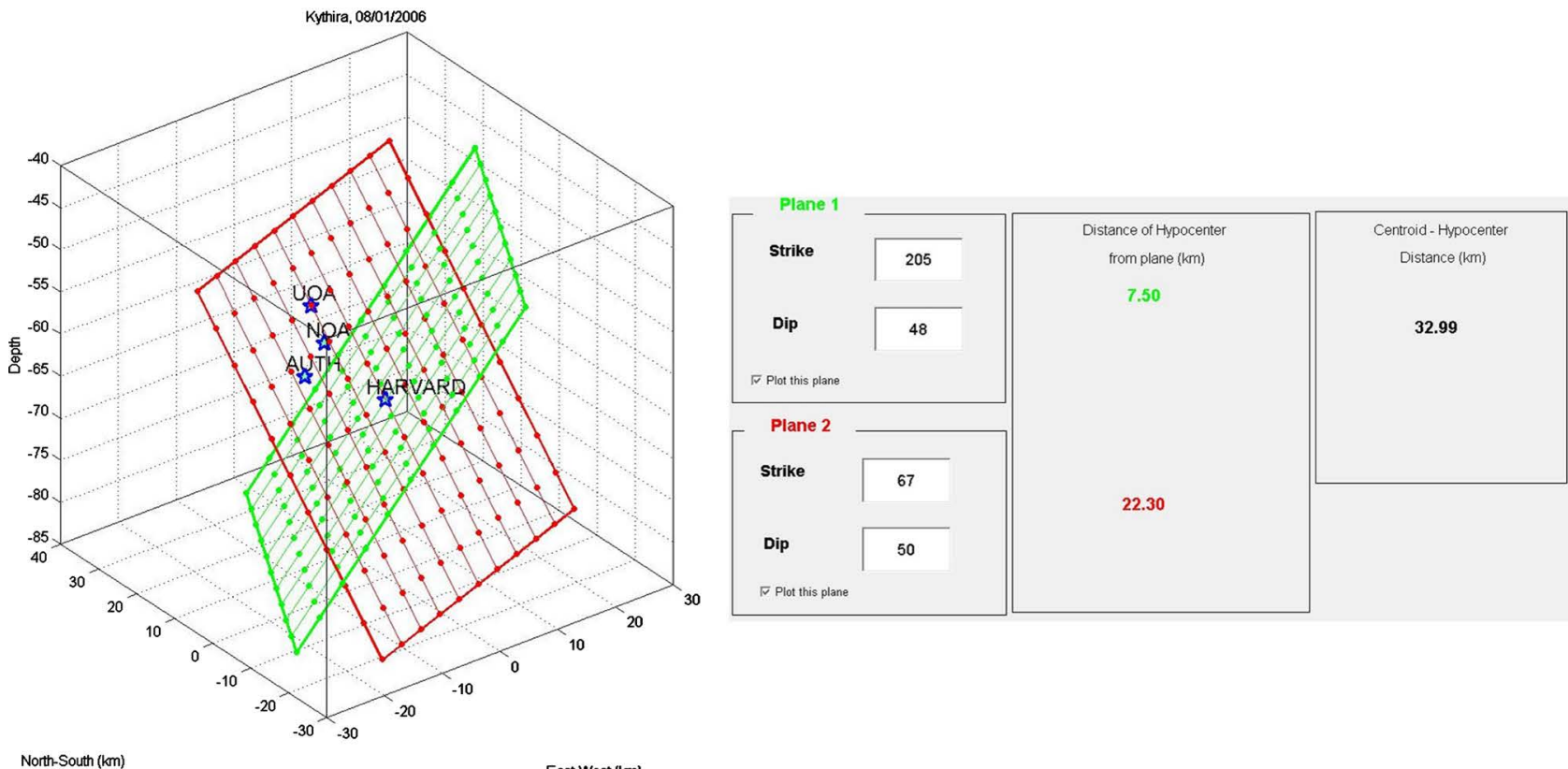

North-South $(\mathrm{km})$

East-West (km)

Figure 3. H-C Plot using the NOA and UOA epicenters (with varying depth), and combining it with the CMT solution of HRV.

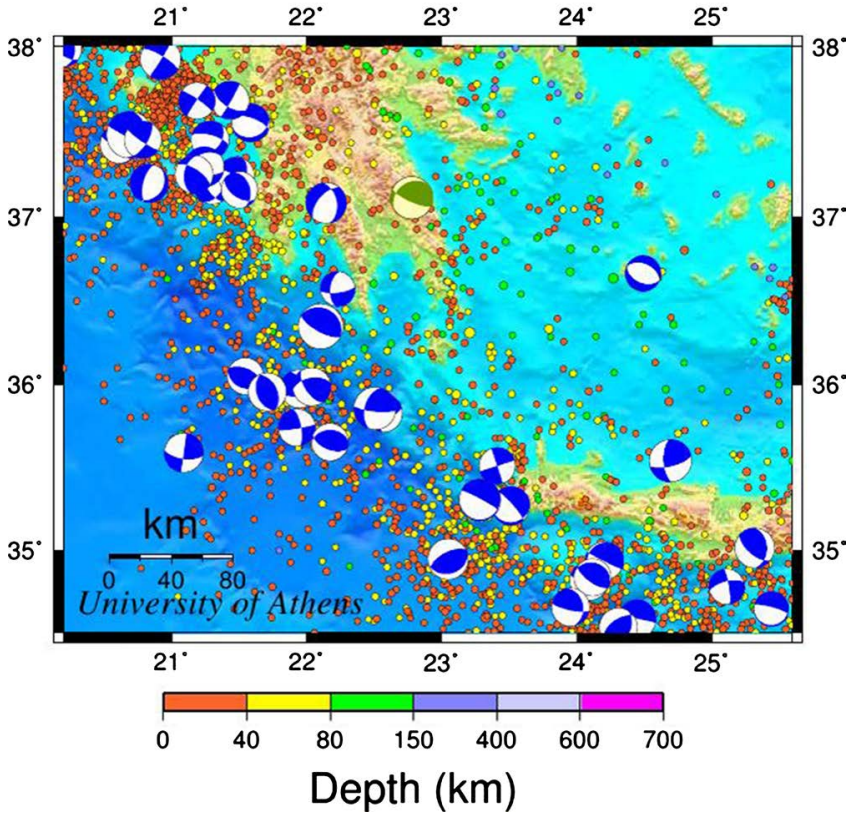

Figure 4. Hypocenter of aftershocks detected and localized using broadband data from Orfeus Institute and Geofon networks, is shown by oranges, yellow and green circles respectively to the depth scale. The focal mechanism of the main event is represented by a green beach ball while blue color appears all the other focal mechanisms in the same region, http://www.geophysics.geol.uoa.gr/imageseis/eqs/2008/20080106 leo/earthquake large e n.html\#meca.

Three-component seismological data from stations belonging to the ORFEUS Institute were used. The inversion procedure provided a thrust type faulting with source parameters: strike $=114^{\circ}, \mathrm{dip}=75^{\circ}$ and rake $=120^{\circ}$. The depth is calculated at $85 \mathrm{~km}$ and the seismic moment $\mathrm{M}_{0}=1.6 \times 10^{25} \mathrm{dyn} \cdot \mathrm{cm}$. The obtained 
result showed a good fit between the observed and the synthetic waveforms (Figure 5).

To apply the HC-plot method, the following 6 hypocenters manually locations (Table 2) were considered.

The fault plane is the nodal plane with strike $=225^{\circ}$, dip $=36^{\circ}$ and strike $=$ $19^{\circ}$. The distance of the hypocenter from this plane is $11.62 \mathrm{~km}$, while the distance from the other plane is $26.30 \mathrm{~km}$. The distance between Hypocenter and Centroid is $33.26 \mathrm{~km}$ (Figure 6). These results are in good agreement with this
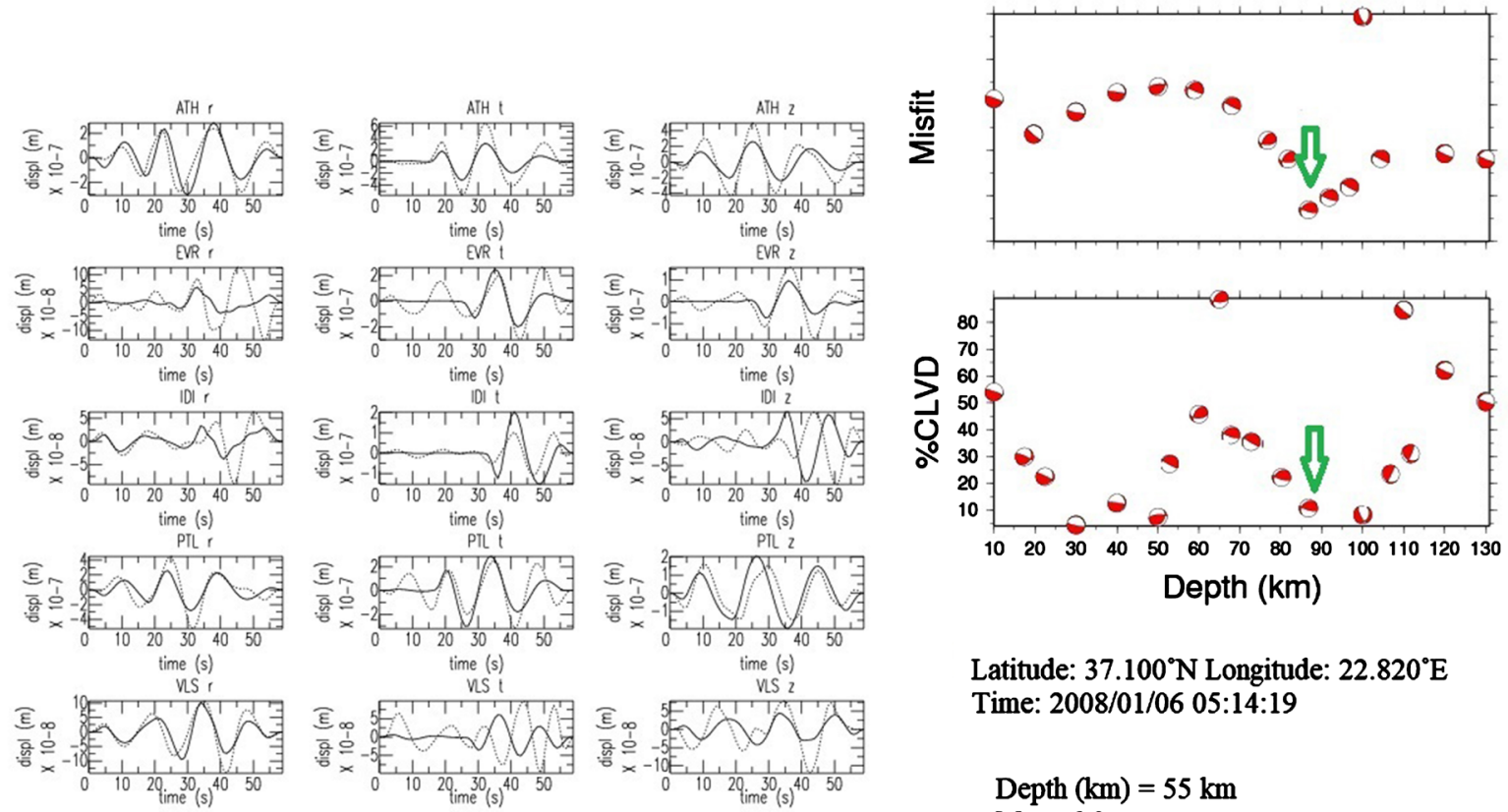

Latitude: $37.100^{\circ} \mathrm{N}$ Longitude: $22.820^{\circ} \mathrm{E}$

Time: 2008/01/06 05:14:19

$$
\begin{aligned}
& \text { Depth }(\mathrm{km})=55 \mathrm{~km} \\
& M_{\mathrm{w}}=6.0 \\
& M_{0}=1.600 \mathrm{E}+25 \mathrm{dyn}^{*} \mathrm{~cm}
\end{aligned}
$$

Plane 1:

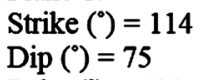

Rake $\left(^{\circ}\right)=120$

Plane 2:

Strike $\left(^{\circ}\right)=228$

Dip $\left(^{\circ}\right)=33$

Rake $\left(^{\circ}\right)=28$

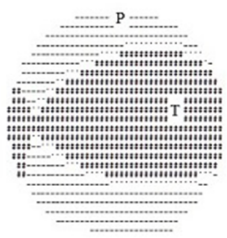

Misfit $=0.30$

$\operatorname{CLVD}(\%)=10$

Quality: A2

Stations Used: ATH, EVR, IDI, PTL, VLS

\section{Computed by: A. Moshou}

Figure 5. Moment tensor solution of the 6 January 2008 (05:14 GMT) earthquake. The selected solution is highlighted with the green arrow in the misfit/CLVD-versus-depth diagrams. Down of this are appeared the summary of the solution and the corresponding beach ball. To the left of misfit/CLVD diagrams observed and synthetic displacement waveforms (continuous and dotted lines respectively) are shown, at the inverted stations for the radial, tangential and vertical components. At the lower part of the figure the summary of the solution and the fault plane solution as lower hemisphere equal-area projection, are depicted. 
Table 2. Manually locations and moment tensor solutions by various agencies. Sources: HARV, INGV, USGS and ETHZ solution.

\begin{tabular}{ccccccccccc}
\hline Agency & Lat $\left(^{\circ}\right)$ & Lon $\left(^{\circ}\right)$ & Depth $(\mathrm{km})$ & $\mathbf{M}_{\mathbf{w}}$ & Strike 1 $\left(^{\circ}\right)$ & Dip 1 $\left(^{\circ}\right)$ & Rake 1 $\left(^{\circ}\right)$ & Strike 2 $\left(^{\circ}\right)$ & Dip 2( $\left(^{\circ}\right)$ & Rake 2 $\left(^{\circ}\right)$ \\
\hline This study & 37.11 & 22.75 & 86 & 6.0 & 120 & 79 & 125 & 225 & 36 & 19 \\
HARV & 36.98 & 22.87 & 92 & 6.1 & 117 & 77 & 130 & 222 & 41 & 20 \\
USGS & 37.30 & 23.00 & 73 & 6.2 & 106 & 79 & 127 & 210 & 38 & 18 \\
ETHZ & 37.10 & 22.70 & 70 & 6.2 & 108 & 74 & 116 & 228 & 30 & 34 \\
INGV & 37.00 & 22.80 & 73 & 6.2 & 113 & 76 & 131 & 219 & 43 & 21 \\
UOA & 37.10 & 22.66 & 75 & 6.0 & 114 & 75 & 120 & 228 & 33 & 28 \\
\hline
\end{tabular}
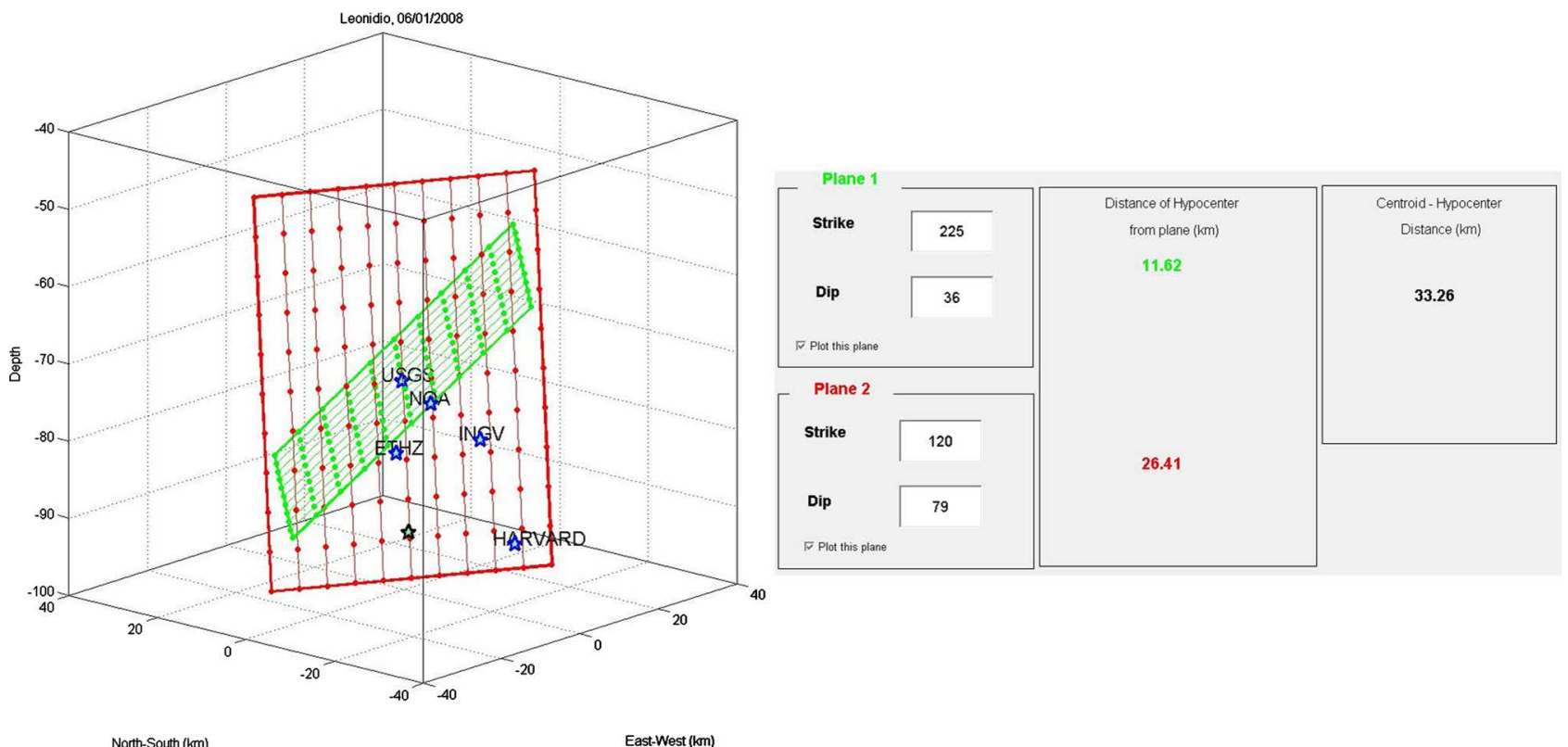

Figure 6. Nodal planes 1 and 2 are shown in green and red rectangular, respectively. The hypocenter solutions of HARV, USGS, INGV, ETHZ and NOA are shown in blue triangle.

one obtained by Zahradnik [2] [3].

\subsection{The Mw = 6.7, and 6.1, 2008 Methoni Earthquakes}

On February 2008 an earthquake sequence including three strong events $(\mathrm{Mw}=$ 6.7, 6.1 and 6.0) occurred South of Methoni town, at a segment of the Hellenic arc which was not activated during the instrumental period. This sequence was followed by a large number of aftershocks, the strongest of which were processed to calculate their source parameters.

The first one occurred on 14 February 2008 (10:09, UTC) and the epicenter was located $\left(36.50^{\circ} \mathrm{N}, 21.78^{\circ} \mathrm{E}\right) 230 \mathrm{~km}$ southwest of Athens. Two hours later (12:08, UTC) the second one occurred close to the first with epicenter $\left(36.22^{\circ} \mathrm{N}\right.$, $21.75^{\circ} \mathrm{E}$ ) and magnitude $\mathrm{Mw}=6.1$, according to the National Observatory of Athens. These two strong events were followed by another earthquake six days later on 20 February 2014 with a similar magnitude $(\mathrm{Mw}=6.0)$. The moment tensor inversion indicates for the two first earthquakes the activation of a thrust- 
faulting type, while for the third event the inversion indicates a strike-slip type faulting.

Following we present the result of the inversion for the first event. For this purpose, the data of 6 stations from Hellenic Unified Seismological Network (HUSN) at epicentral distances less than $360 \mathrm{~km}$, were used. Reverse type faulting was revealed after applying inversion. The obtained focal mechanism is strike $=290^{\circ}$, dip $=16^{\circ}$ and rake $=69^{\circ}$. The seismic moment is equal to M0 $=$ $1.56 \times 10^{26} \mathrm{dyn} \cdot \mathrm{cm}$, for a focal depth equal to $29 \mathrm{~km}$ (Figure 7). The inversion
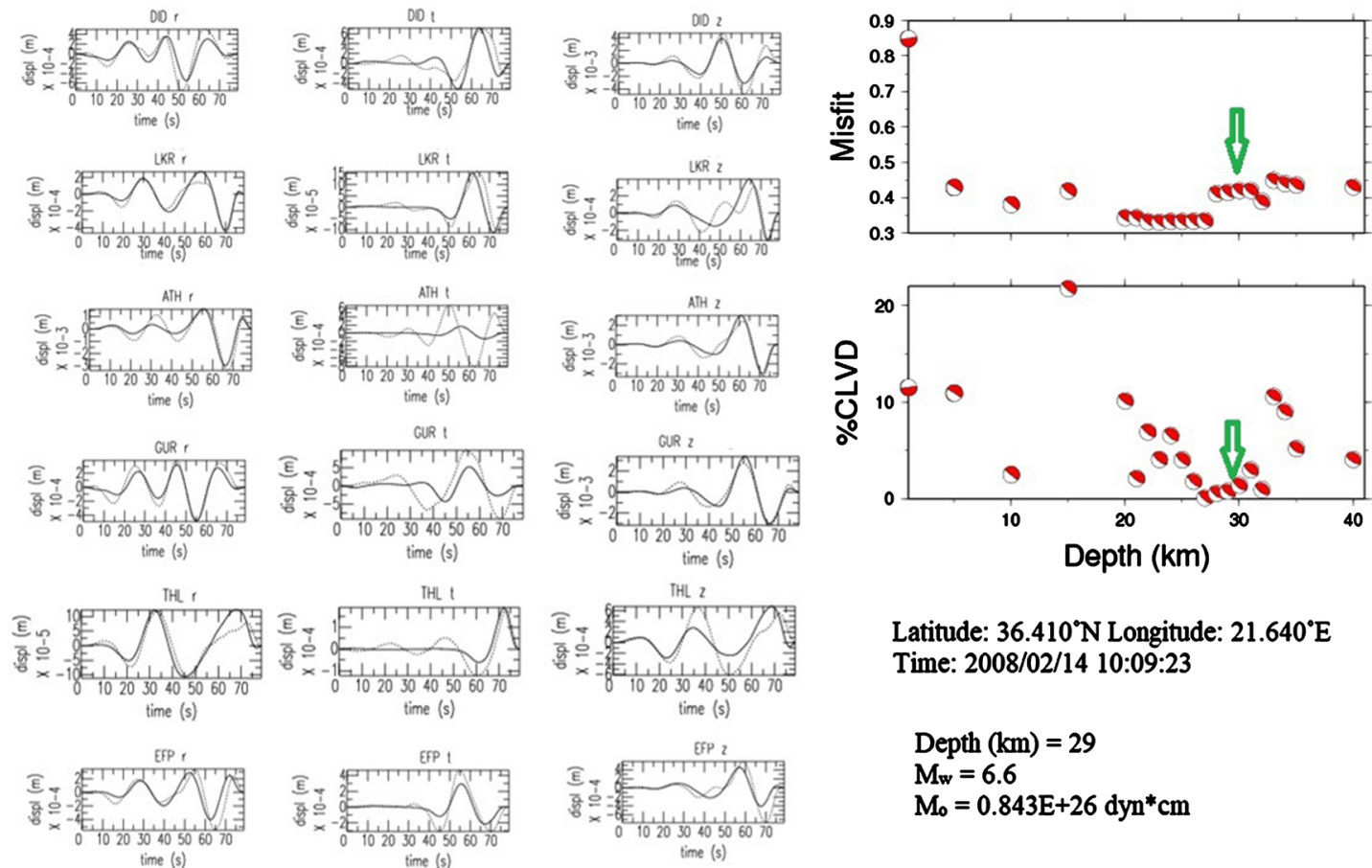
Latitude: $36.410^{\circ} \mathrm{N}$ Longitude: $21.640^{\circ} \mathrm{E}$
Time: $2008 / 02 / 14$ 10:09:23

$$
\begin{aligned}
& \text { Depth }(\mathrm{km})=29 \\
& M_{w}=6.6 \\
& M_{0}=0.843 E+26 \text { dyn*cm }
\end{aligned}
$$

Plane 1:

Strike $\left(^{\circ}\right)=300$

$\operatorname{Dip}\left(^{\circ}\right)=20$

Rake $\left({ }^{\circ}\right)=73$

Plane 2:

Strike $\left({ }^{\circ}\right)=138$

$\operatorname{Dip}\left(^{\circ}\right)=71$

Rake $\left({ }^{\circ}\right)=96$

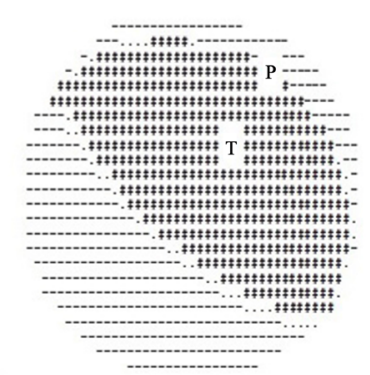

Misfit $=0.22$

$\operatorname{CLVD}(\%)=10$

Quality: Al

Stations Used: DID, LKR, ATH, GUR, THL, EFP

\section{Computed by: A. Moshou}

Figure 7. Moment tensor solution of the 14 February 2008 (10:09, UTC) earthquake. The selected solution is highlighted with the green arrow in the misfit/CLVD-versus-depth diagrams. Down of this are appeared the summary of the solution and the corresponding beach ball. To the left of misfit/CLVD diagrams observed and synthetic displacement waveforms (continuous and dotted lines respectively) are shown, at the inverted stations for the radial, tangential and vertical components. At the lower part of the figure the summary of the solution and the fault plane solution as lower hemisphere equal-area projection, is depicted. 
resulted in a DC equal to $90 \%$, while the compensated linear vector dipole was equal to $10 \%$. To determine the main fault four representative solutions selected, are presented in Table 3 and are plotted later in Figure 8.

Table 3. Manually locations and Moment Tensor Solutions by various agencies. Sources: HARV, INGV, USGS and AUTH solution.

\begin{tabular}{ccccccccccc}
\hline Agency & Lat $\left(^{\circ}\right)$ & Lon $\left(^{\circ}\right)$ & Depth $(\mathbf{k m})$ & $\mathbf{M}_{\mathbf{w}}$ & Strike 1 $\left(^{\circ}\right)$ & Dip 1 $\left(^{\circ}\right)$ & Rake 1 $\left(^{\circ}\right)$ & Strike 2 $\left(^{\circ}\right)$ & Dip 2 $\left(^{\circ}\right)$ & Rake 2 $\left(^{\circ}\right)$ \\
\hline This study & 36.50 & 21.78 & 29 & 300 & 20 & 73 & 138 & 71 & 96 & 36.50 \\
HARV & 36.30 & 21.80 & 17 & 331 & 6 & 117 & 124 & 85 & 87 & 36.30 \\
USGS & 36.80 & 22.00 & 29 & 126 & 80 & 87 & 323 & 10 & 107 & 36.80 \\
INGV & 36.20 & 21.50 & 39 & 333 & 17 & 111 & 131 & 74 & 84 & 36.20 \\
AUTH & 36.50 & 21.80 & 35 & 131 & 77 & 92 & 302 & 13 & 81 & 36.50 \\
UOA & 36.30 & 21.69 & 35 & 290 & 16 & 69 & 132 & 75 & 96 & 36.30 \\
\hline
\end{tabular}

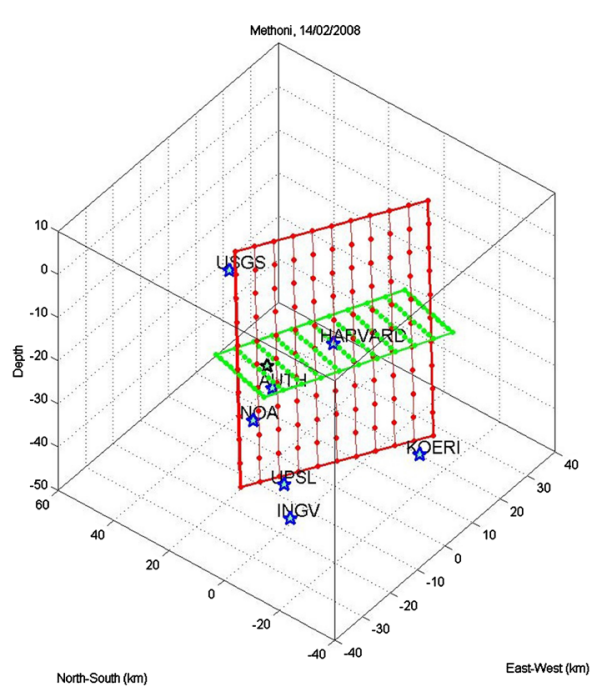

North-South (km)

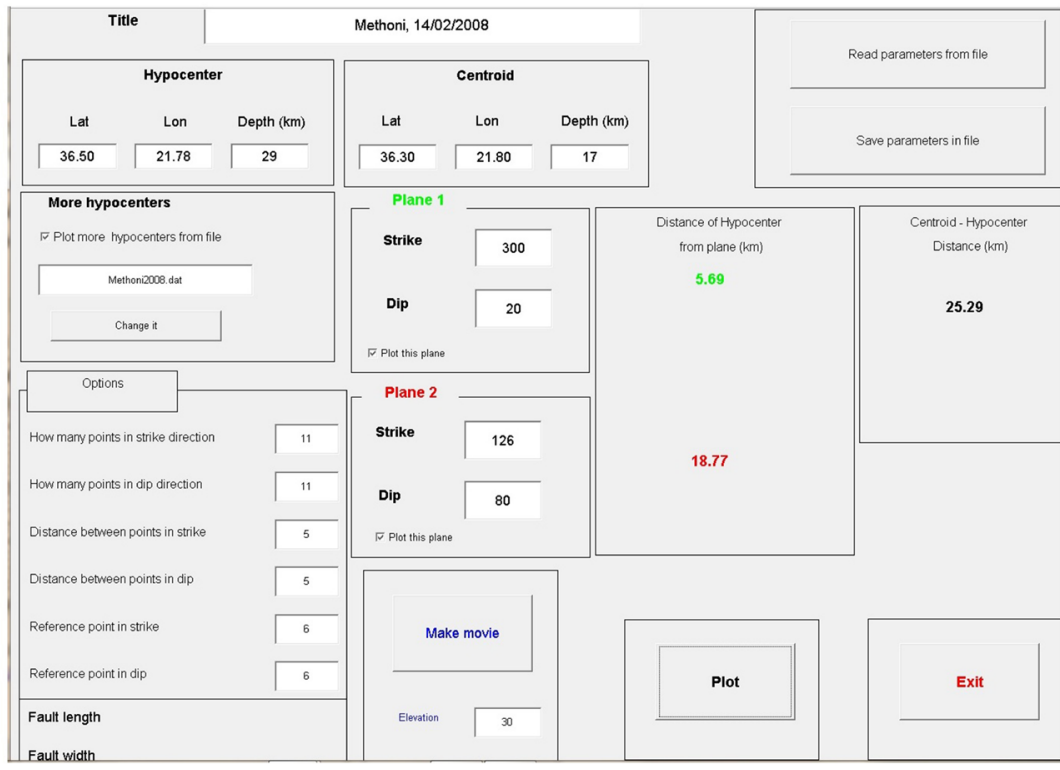

Figure 8. H-C Plot using the UPSL hypocenter (green star), hypocenters of other agencies (USGS, HRV, AUTH, NOA, UPSL and INGV, blue stars).

\subsection{The $M w=6.4,2008$ Andravida Earthquake}

On June 8, 2008 (12:25 GMT) a strong earthquake with a moment magnitude $\mathrm{M}_{\mathrm{w}}=6.4$ occurred in the region of Peloponnese, W. Greece close to Andravida city. The area is located between the Gulf of Corinth extensional province and the Eurasia-Africa plate boundary offshore Cephalonia and Zakynthos Islands. No surface rupture was observed.

The epicentral coordinates were $37.98^{\circ} \mathrm{N}, 21.51^{\circ} \mathrm{E}$, after these events a large number of aftershocks were followed. Double-difference relocations of 370 aftershocks show a linear pattern of events and define a clear NE-SW striking mainshock fault plane (Ganas et al., 2009). The hypocenter was determined at 18 $\mathrm{km}$ depth beneath village Mihoi in SW Achaia.

The constrained focal mechanism solution indicates strike-slip faulting with 
source parameters strike $=290^{\circ}, \operatorname{dip}=70^{\circ}$ and rake $=1^{\circ}$, the seismic moment is equal to $\mathrm{M}_{0}=4.49 \times 10^{25} \mathrm{dyn} \cdot \mathrm{cm}$, while the focal depth was equal to $22 \mathrm{~km}$ (Figure 9). Taking to account the aftershock activity the fault plane is the one with the NE-SW direction.

To apply the HC-plot method, the following 6 hypocenters manually locations (Table 4) were considered.

The following CMT solutions were considered: HRV, USGS, ETHZ, INGV, AUTH and NOA (Figure 10). All these solutions are characterized by similar strike-dip-rake angles, with one nodal plane, strike $265^{\circ}$, dip $\sim 5^{\circ}$ and rake $4^{\circ}$ plotted in green and hereafter referred to as the green plane and the other one, strike $300^{\circ}, \operatorname{dip} \sim 75^{\circ}$ and rake $160^{\circ}$ as the red plane (Figure 10).

The fault plane is the nodal plane with strike $=290^{\circ}, \operatorname{dip}=70^{\circ}$ and strike $=1^{\circ}$.
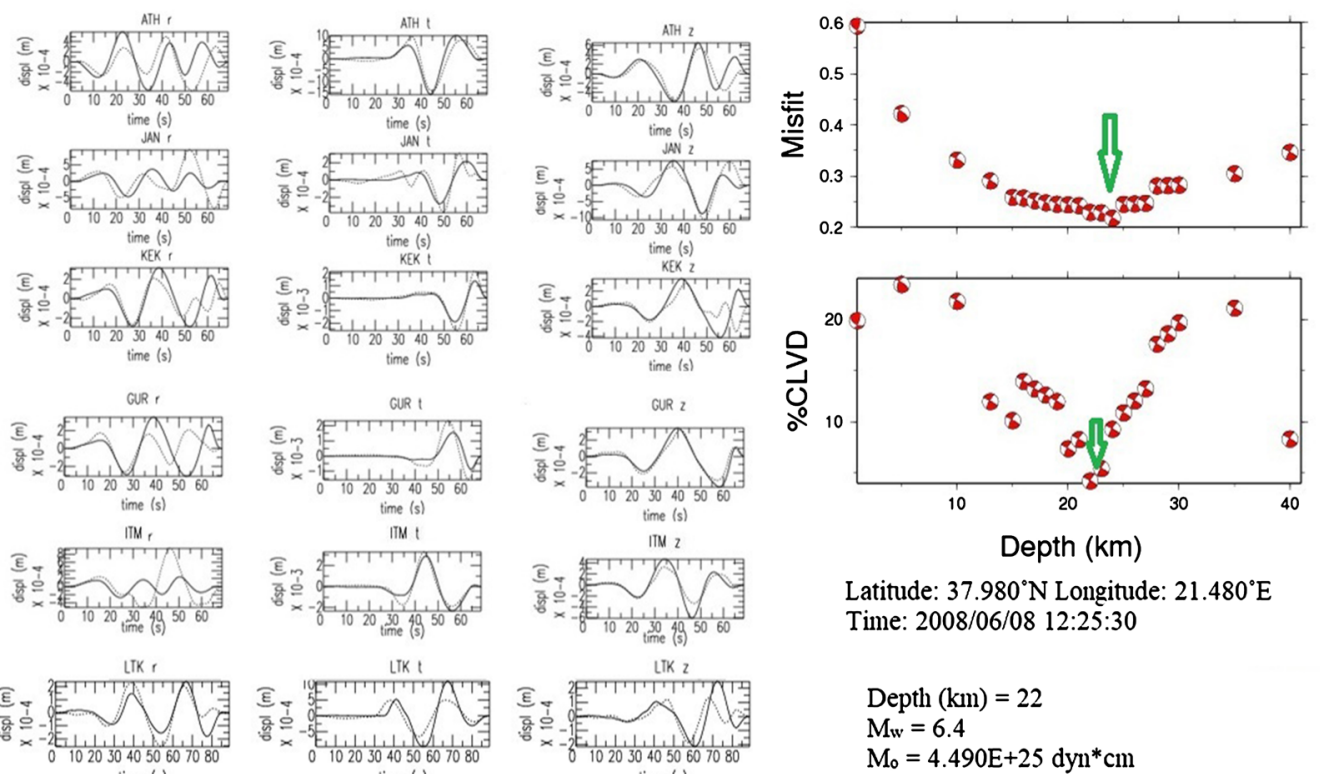

Depth (km)

Latitude: $37.980^{\circ} \mathrm{N}$ Longitude: $21.480^{\circ} \mathrm{E}$

Time: 2008/06/08 12:25:30

$$
\begin{aligned}
& \text { Depth }(\mathrm{km})=22 \\
& M_{w}=6.4 \\
& M_{\circ}=4.490 E+25 \text { dyn*cm }
\end{aligned}
$$

Plane 1:

Strike $\left(^{\circ}\right)=123$

$\operatorname{Dip}\left(^{\circ}\right)=70$

Rake $\left({ }^{\circ}\right)=1$

Plane 2:

Strike $\left(^{\circ}\right)=33$

$\operatorname{Dip}\left({ }^{\circ}\right)=90$

Rake $\left(^{\circ}\right)=160$

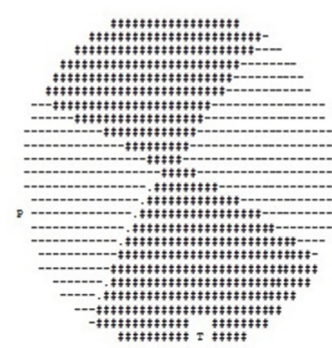

Misfit $=0.23$

$\operatorname{CLVD}(\%)=4.2$

Quality: A1

Stations Used: ITM, GUR, LTK, ATH, KEK, JAN

Computed by: A. Moshou

Figure 9. Moment tensor solution of the event that occurred on 8 June 2008 (12:25, GMT). The selected solution is highlighted with the green arrow in the misfit/CLVD-versus-depth diagrams. Down of this are appeared the summary of the solution and the corresponding beach ball. To the left of misfit/CLVD diagrams we present observed and synthetic displacement waveforms (continuous and dotted lines respectively) at the inverted stations for the radial, tangential and vertical components. 
Table 4. Hypocenter position from manually locations and focal mechanism by various agencies, by various agencies, http://www.emsc-csem.org/Earthquake/tensors.php?id=88518\&id2=j3155;INFO.

\begin{tabular}{ccccccccccc}
\hline Agency & Lat $\left(^{\circ}\right)$ & Lon $\left(^{\circ}\right)$ & Depth $(\mathbf{k m})$ & $\mathbf{M}_{\mathbf{w}}$ & Strike 1 $\left(^{\circ}\right)$ & Dip 1 $\left(^{\circ}\right)$ & Rake 1 $\left(^{\circ}\right)$ & Strike 2 $\left(^{\circ}\right)$ & Dip 2( $\left(^{\circ}\right)$ & Rake 2 $\left.^{\circ}\right)$ \\
\hline This study & 38.00 & 21.50 & 22 & 6.4 & 290 & 70 & 1 & 200 & 89 & 160 \\
USGS & 38.10 & 21.60 & 10 & 6.3 & 300 & 70 & 1 & 210 & 89 & 161 \\
HARVARD & 38.00 & 21.60 & 15 & 6.3 & 301 & 72 & 4 & 210 & 86 & 162 \\
INGV & 38.00 & 21.50 & 38 & 6.5 & 210 & 85 & 179 & 300 & 89 & 5 \\
ETHZ & 38.00 & 21.40 & 31 & 6.4 & 305 & 75 & 8 & 213 & 82 & 165 \\
AUTH & 38.00 & 21.50 & 30 & 6.5 & 211 & 90 & 178 & 301 & 88 & 1 \\
\hline
\end{tabular}
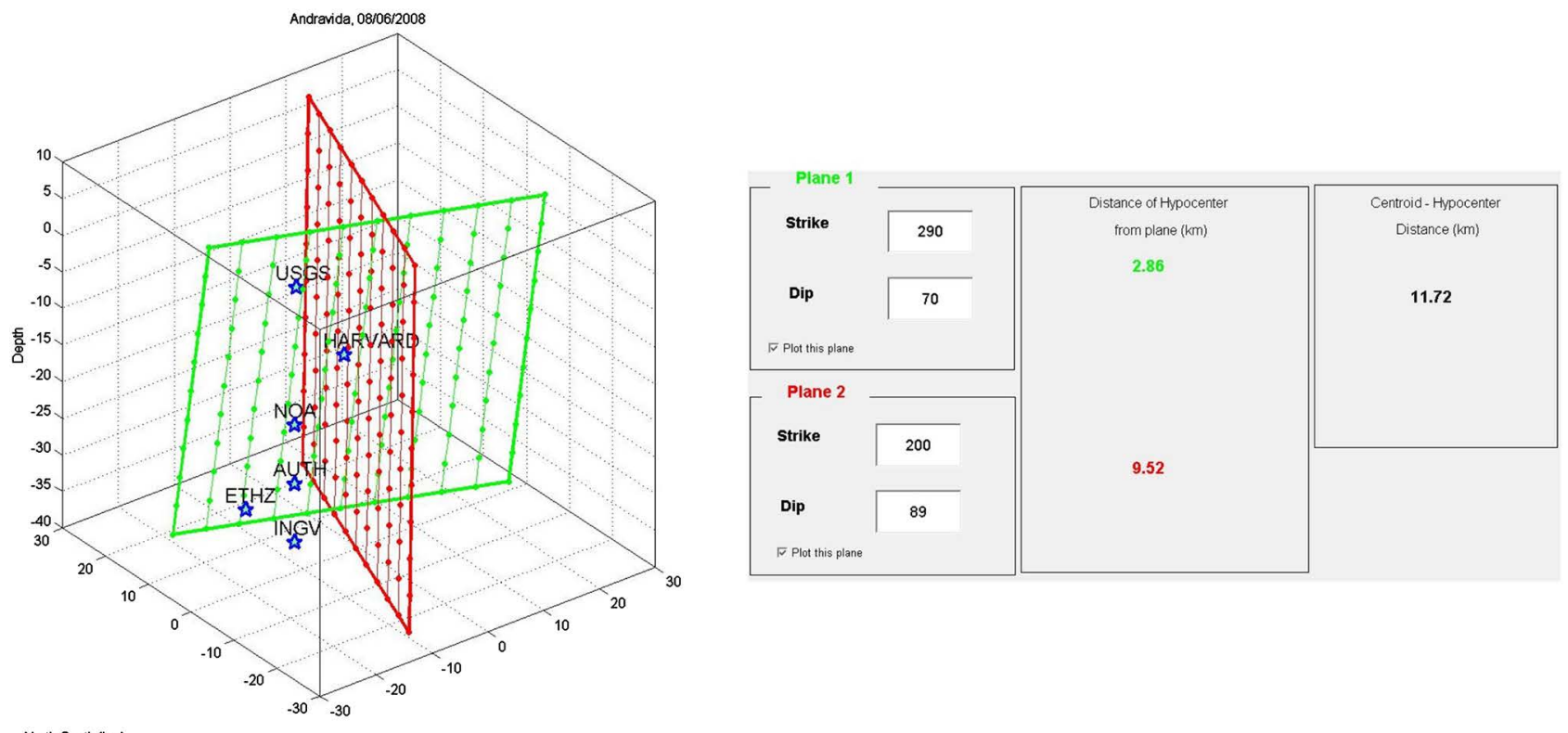

North-South $(\mathrm{km})$

East-West (km)

Figure 10. Nodal planes 1 and 2 are shown in red and green, respectively. The depth that calculated by USGS, HARV, INGV, ETHZ and AUTH institutes are representing with blue triangle.

The distance of the hypocenter from this plane is $2.86 \mathrm{~km}$, while the distance from the other plane is $9.52 \mathrm{~km}$. The distance between Hypocenter and Centroid is $11.72 \mathrm{~km}$ (Figure 11). This result is in good agreement with those from other studies [2] [3] [13].

Following we present the inversions results for 28 events with magnitudes $\mathrm{M}_{\mathrm{w}}>3.5$ that occurred in the same region (Table 5).

\subsection{The $M_{w}=5.7,2013$ Limnos Earthquake}

On 8 January 2013 at 14:16:08.3 UTC, a moderate earthquake of magnitude Mw $=5.7$ occurred off the southern coast of Limnos island. The event was strongly felt in nearby north Aegean islands, the neighboring Turkish coasts and the northeastern Greek mainland but caused no damage [14]. The epicenter was manually located at $39.6663^{\circ} \mathrm{N}, 25.5620^{\circ} \mathrm{E}$, depth $=31 \mathrm{~km}$ with a local magnitude $\mathrm{M}_{\mathrm{L}}=5.8$ according to National Observatory of Athens, 
http://bbnet.gein.noa.gr/alerts_manual/2013/01/evman130108141608_info.html.

The location of the earthquake indicates that it ruptured a fault segment running south of the North Aegean Trough near the island of Limnos [15] [16] [17], where the main, northern branch of the North Anatolian Fault (NAF) enters

Table 5. Moment Tensors Solutions for 28 studied events $\left(M_{w} \geq 3.5\right)$ of the Andravida Sequence (06/08/2008-18/06/2008). Columns (from left to right) show: event number, date and origin time, latitude and longitude of the epicenter, seismic moment, moment magnitude, the depth of the location and the depth as it calculated by the moment tensor inversion, strike dip and rake of the two nodal planes.

\begin{tabular}{|c|c|c|c|c|c|c|c|c|c|c|c|c|c|}
\hline \multirow[b]{2}{*}{$\mathrm{N} / \mathrm{N}$} & \multicolumn{2}{|c|}{ Origin Time } & \multicolumn{2}{|c|}{ Location } & \multicolumn{2}{|c|}{ Magnitude } & \multirow[t]{2}{*}{$\mathbf{M}_{\mathrm{w}}$} & \multicolumn{3}{|c|}{ Nodal Plane 1} & \multicolumn{3}{|c|}{ Nodal Plane 2} \\
\hline & $\begin{array}{c}\text { Date } \\
(\mathrm{D} / \mathrm{M} / \mathrm{Y})\end{array}$ & $\begin{array}{l}\text { Time } \\
\text { (UTC) }\end{array}$ & $\begin{array}{l}\text { Lat } \\
\left({ }^{\circ}\right)\end{array}$ & $\begin{array}{l}\text { Lon } \\
\left({ }^{\circ}\right)\end{array}$ & $\begin{array}{c}\mathrm{M}_{0} \\
\left(\mathrm{dyn}{ }^{*} \mathrm{~cm}\right)\end{array}$ & $\begin{array}{c}\text { Depth } \\
(\mathrm{km})\end{array}$ & & $\begin{array}{c}\text { Strike } \\
\left({ }^{\circ}\right)\end{array}$ & $\begin{array}{l}\text { Dip } \\
\left({ }^{\circ}\right)\end{array}$ & $\begin{array}{c}\text { Rake } \\
\left({ }^{\circ}\right)\end{array}$ & $\begin{array}{l}\text { Strike } \\
\left({ }^{\circ}\right)\end{array}$ & $\begin{array}{l}\text { Dip } \\
\left({ }^{\circ}\right)\end{array}$ & $\begin{array}{c}\text { Rake } \\
\left({ }^{\circ}\right)\end{array}$ \\
\hline 1 & 08/06/2008 & $12: 25: 28.180$ & 37.9727 & 21.5157 & $4.60 \mathrm{E}+25$ & 20.0 & 6.4 & 290.0 & 70.0 & 1.0 & 200 & 89 & 160 \\
\hline 2 & 08/06/2008 & 12:40:53.958 & 38.1069 & 21.5651 & $4.30 \mathrm{E}+21$ & 15.0 & 3.7 & 330.0 & 65.0 & 30.0 & 226 & 63 & 152 \\
\hline 3 & 08/06/2008 & $12: 43: 39.173$ & 38.0280 & 21.6107 & $1.60 \mathrm{E}+23$ & 15.0 & 4.7 & 316.0 & 65.0 & 22.0 & 216 & 70 & 153 \\
\hline 4 & 08/06/2008 & $12: 46: 53.112$ & 38.0861 & 21.6454 & $7.00 \mathrm{E}+21$ & 13.0 & 3.8 & 320.0 & 61.0 & 17.0 & 222 & 75 & 150 \\
\hline 5 & 08/06/2008 & $12: 55: 13.978$ & 38.1104 & 21.6325 & $2.80 \mathrm{E}+21$ & 13.0 & 3.6 & 330.0 & 78.0 & 20.0 & 236 & 70 & 167 \\
\hline 6 & 08/06/2008 & $13: 20: 30.038$ & 38.0551 & 21.5630 & $2.10 \mathrm{E}+21$ & 10.0 & 3.6 & 290.0 & 72.0 & 35.0 & 188 & 57 & 158 \\
\hline 7 & 08/06/2008 & $13: 27: 49.114$ & 38.0958 & 21.5940 & $2.80 \mathrm{E}+21$ & 18.0 & 3.6 & 320.0 & 61.0 & 17.0 & 222 & 75 & 150 \\
\hline 8 & 08/06/2008 & $13: 31: 34.668$ & 38.0129 & 21.5616 & $7.60 \mathrm{E}+21$ & 25.0 & 3.9 & 356.0 & 65.0 & 27.0 & 254 & 66 & 152 \\
\hline 9 & 08/06/2008 & $13: 41: 47.828$ & 37.9734 & 21.5114 & $6.80 \mathrm{E}+21$ & 43.0 & 3.8 & 275.0 & 35.0 & 45.0 & 146 & 66 & 116 \\
\hline 10 & 08/06/2008 & 14:01:07.601 & 38.0868 & 21.5968 & $6.81 \mathrm{E}+21$ & 20.0 & 3.8 & 300.0 & 75.0 & -15.0 & 34 & 76 & -164 \\
\hline 11 & 08/06/2008 & $14: 16: 25.262$ & 38.0975 & 21.5783 & $3.70 \mathrm{E}+21$ & 21.0 & 3.6 & 300.0 & 55.0 & 30.0 & 192 & 66 & 141 \\
\hline 12 & 08/06/2008 & $14: 22: 29.173$ & 38.0676 & 21.5783 & $5.50 \mathrm{E}+21$ & 20.0 & 3.8 & 300.0 & 75.0 & -15.0 & 34 & 76 & -164 \\
\hline 13 & 08/06/2008 & $16: 10: 06.321$ & 37.9951 & 21.5388 & $6.80 \mathrm{E}+21$ & 15.0 & 3.8 & 30.0 & 90.0 & 150.0 & 120 & 60 & 1 \\
\hline 14 & 08/06/2008 & $17: 56: 03.654$ & 38.0857 & 21.5875 & $2.30 \mathrm{E}+21$ & 15.0 & 3.5 & 330.0 & 60.0 & 29.0 & 225 & 65 & 147 \\
\hline 15 & 08/06/2008 & $18: 12: 39.103$ & 37.9770 & 21.5234 & $2.70 \mathrm{E}+21$ & 17.0 & 3.5 & 208.0 & 80.0 & 170.0 & 300 & 80 & 10 \\
\hline 16 & 08/06/2008 & $18: 42: 25.763$ & 38.0330 & 21.5549 & $3.76 \mathrm{E}+21$ & 17.0 & 3.7 & 318.0 & 70.0 & 27.0 & 218 & 65 & 158 \\
\hline 17 & 08/06/2008 & $20: 36: 23.571$ & 38.1173 & 21.5926 & $2.40 \mathrm{E}+21$ & 22.0 & 3.5 & 310.0 & 65.0 & 23.0 & 210 & 69 & 153 \\
\hline 18 & $08 / 06 / 2008$ & $21: 10: 22.743$ & 38.0014 & 21.5788 & $3.90 \mathrm{E}+22$ & 21.0 & 4.3 & 310.0 & 69.0 & 15.0 & 215 & 76 & 158 \\
\hline 19 & $08 / 06 / 2008$ & 21:48:30.423 & 37.9895 & 21.5296 & $7.93 \mathrm{E}+21$ & 20.0 & 3.9 & 33.0 & 90.0 & 160.0 & 123 & 70 & 1 \\
\hline 20 & 09/06/2008 & 01:32:03.476 & 38.0639 & 21.5667 & $3.70 \mathrm{E}+21$ & 21.0 & 4.2 & 330.0 & 55.0 & 30.0 & 220 & 67 & 136 \\
\hline 21 & $09 / 06 / 2008$ & 11:51:59.347 & 38.1536 & 21.5830 & $2.80 \mathrm{E}+21$ & 19.0 & 3.5 & 315.0 & 72.0 & 19.0 & 219 & 72 & 161 \\
\hline 22 & $09 / 06 / 2008$ & 13:53:21.609 & 38.0312 & 21.5513 & $2.30 \mathrm{E}+22$ & 18.0 & 4.2 & 316.0 & 65.0 & 22.0 & 216 & 70 & 153 \\
\hline 23 & 09/06/2008 & $16: 18: 40.590$ & 38.0713 & 21.5678 & $1.90 \mathrm{E}+22$ & 18.0 & 4.1 & 320.0 & 72.0 & 22.0 & 223 & 69 & 161 \\
\hline 24 & $10 / 06 / 2008$ & $20: 45: 17.632$ & 38.0444 & 21.5626 & $3.76 \mathrm{E}+21$ & 18.0 & 3.7 & 300.0 & 55.0 & 30.0 & 192 & 66 & 141 \\
\hline 25 & $11 / 06 / 2008$ & 01:05:03.649 & 37.9505 & 21.4908 & $2.80 \mathrm{E}+21$ & 22.0 & 3.5 & 320.0 & 61.0 & 17.0 & 222 & 75 & 150 \\
\hline 26 & $11 / 06 / 2008$ & $16: 09: 43.337$ & $38.014: 7$ & 21.5562 & $2.80 \mathrm{E}+21$ & 17.0 & 3.5 & 316.0 & 65.0 & 22.0 & 216 & 70 & 153 \\
\hline 27 & $12 / 06 / 2008$ & 03:15:33.988 & 38.0132 & 21.6093 & $2.80 \mathrm{E}+21$ & 22.0 & 4.2 & 326.0 & 70.0 & 20.0 & 229 & 71 & 159 \\
\hline 28 & $18 / 06 / 2008$ & $17: 57: 26.520$ & 38.1053 & 21.5921 & $4.30 \mathrm{E}+21$ & 15.0 & 3.7 & 330.0 & 60.0 & 28.0 & 225 & 66 & 147 \\
\hline
\end{tabular}


Aegean Sea [18] [19] [20].

The main event of January 8, 2013, was followed by a large number of aftershocks. For the next two months, a total number of 495 events $\left(1 \leq \mathrm{M}_{\mathrm{L}} \leq 4.5\right)$ were recorded and analyzed. The main shock, as well as the aftershocks were relocated [21]. The aftershock distribution of the mainshock reveals a NE-SW stricking fault about $40 \mathrm{~km}$ offshore Limnos Island that extends from $2 \mathrm{~km}$ up to a depth of $14 \mathrm{~km}$ [21]. The next two months 7 events with magnitude $\mathrm{M}_{\mathrm{w}} \geq 3.7$ occurred and the source parameters of them calculated and presented in Table 6 .

We applied moment tensor inversion to calculate the source parameters of the main event (January 8, 2013 14:16, UTC). Seismological data from HUSN, of 8 stations at epicentral distances less than $350 \mathrm{~km}$ were used. A band-passed filtering at frequencies $0.05-0.08 \mathrm{~Hz}$ was used both of recorded waveforms of three components and calculated synthetics seismograms. The inversion indicated a strike slip faulting, and the source parameters were calculated: strike $=$ $315^{\circ}$, dip $=86^{\circ}$, rake $=5^{\circ}$ with a depth $8 \mathrm{~km}$ while the moment magnitude determined $\mathrm{M}_{0}=3.90 \times 10^{24} \mathrm{dyn} \cdot \mathrm{cm}$. The calculated double couple found $95 \%$ (Figure 11).

To apply the HC-plot method, the followed 7 hypocenters manually locations (Table 7) were considered.

The following CMT solutions were considered: HRV, USGS, GFZ, INGV, AUTH and UOA (Figure 13). All these solutions are characterized by similar strike-dip-rake angles, with one nodal plane, strike $300^{\circ}$, dip $80^{\circ}$ plotted in green and hereafter referred to as the "green" plane and the other one dipping, strike $65^{\circ} \mathrm{deg}$, dip $\sim 80^{\circ}$ as the "red" plane. The distance of hypocenter from this plane is $6.11 \mathrm{~km}$, while the distance from the other plane is $1.61 \mathrm{~km}$. The distance between Hypocenter and Centroid is $6.89 \mathrm{~km}$ (Figure 12). The main fault is this with source parameters: strike $=45^{\circ}$, dip $=85^{\circ}$ and rake $=-175^{\circ}$ and it is in agreement with these from the study [13].

Table 6. Moment Tensors Solutions for 7 studied events $\left(M_{W} \geq 3.7\right)$ of the Limnos Sequence (08/01/2013-08/03/2013), columns (from left to right) show: event number, date and origin time, latitude and longitude of the epicenter, seismic moment, moment magnitude, the depth as it calculated by the moment tensor inversion, strike dip and rake of the two nodal planes

\begin{tabular}{|c|c|c|c|c|c|c|c|c|c|c|c|c|c|}
\hline \multirow[b]{2}{*}{ NR } & \multicolumn{2}{|c|}{ Origin Time } & \multicolumn{2}{|c|}{ Location } & \multicolumn{2}{|c|}{ Magnitude } & \multirow{2}{*}{$\begin{array}{c}\text { Depth }(\mathrm{km}) \\
\text { Inversion }\end{array}$} & \multicolumn{3}{|c|}{ Nodal Plane 1} & \multicolumn{3}{|c|}{ Nodal Plane 2} \\
\hline & $\begin{array}{c}\text { Date } \\
(\mathrm{D} / \mathrm{M} / \mathrm{Y})\end{array}$ & $\begin{array}{l}\text { Time } \\
\text { (UTC) }\end{array}$ & $\begin{array}{l}\text { Lat } \\
\left({ }^{\circ}\right)\end{array}$ & $\begin{array}{l}\text { Lon } \\
\left({ }^{\circ}\right)\end{array}$ & $M_{0}\left(\operatorname{dyn}^{*} \mathrm{~cm}\right)$ & Mw & & $\begin{array}{c}\text { Strike } \\
\left({ }^{\circ}\right)\end{array}$ & $\begin{array}{l}\text { Dip } \\
\left({ }^{\circ}\right)\end{array}$ & $\begin{array}{l}\text { Rake } \\
\left({ }^{\circ}\right)\end{array}$ & $\begin{array}{l}\text { Strike } \\
\left(^{\circ}\right)\end{array}$ & $\begin{array}{l}\text { Dip } \\
\left({ }^{\circ}\right)\end{array}$ & Rake ( $\left(^{\circ}\right)$ \\
\hline 1 & $09 / 01 / 2013$ & $15: 41: 32.4$ & 39.6872 & 25.5970 & $0.515 \mathrm{E}+23$ & 4.4 & 7 & 88 & 63 & -129 & 310 & 67 & -25 \\
\hline 2 & $10 / 01 / 2013$ & $05: 49: 58.2$ & 39.6618 & 25.5173 & $0.576 \mathrm{E}+22$ & 3.8 & 6 & 68 & 56 & -176 & 335 & 86 & -34 \\
\hline 3 & $11 / 01 / 2013$ & $00: 30: 20.5$ & 39.6623 & 25.5088 & $0.205 E+23$ & 4.2 & 9 & 331 & 78 & -5 & 62 & 85 & -168 \\
\hline 4 & $11 / 01 / 2013$ & $15: 07: 31.0$ & 39,6982 & 25,5878 & $0.576 \mathrm{E}+22$ & 3.8 & 8 & 60 & 89 & -168 & 328 & 78 & -4 \\
\hline 5 & $13 / 01 / 2013$ & $08: 55: 14.6$ & 39.6627 & 25.5148 & $0.515 \mathrm{E}+23$ & 4.4 & 7 & 58 & 71 & -173 & 326 & 84 & -19 \\
\hline 6 & $13 / 01 / 2013$ & $17: 54: 32.0$ & 39.6462 & 25.6013 & $0.409 \mathrm{E}+22$ & 3.7 & 7 & 60 & 75 & -175 & 323 & 86 & -23 \\
\hline 7 & $05 / 03 / 2013$ & 9:44:33.00 & 39.7023 & 25.5572 & $0.576 \mathrm{E}+22$ & 3.8 & 8 & 64 & 50 & -157 & 330 & 80 & -30 \\
\hline
\end{tabular}



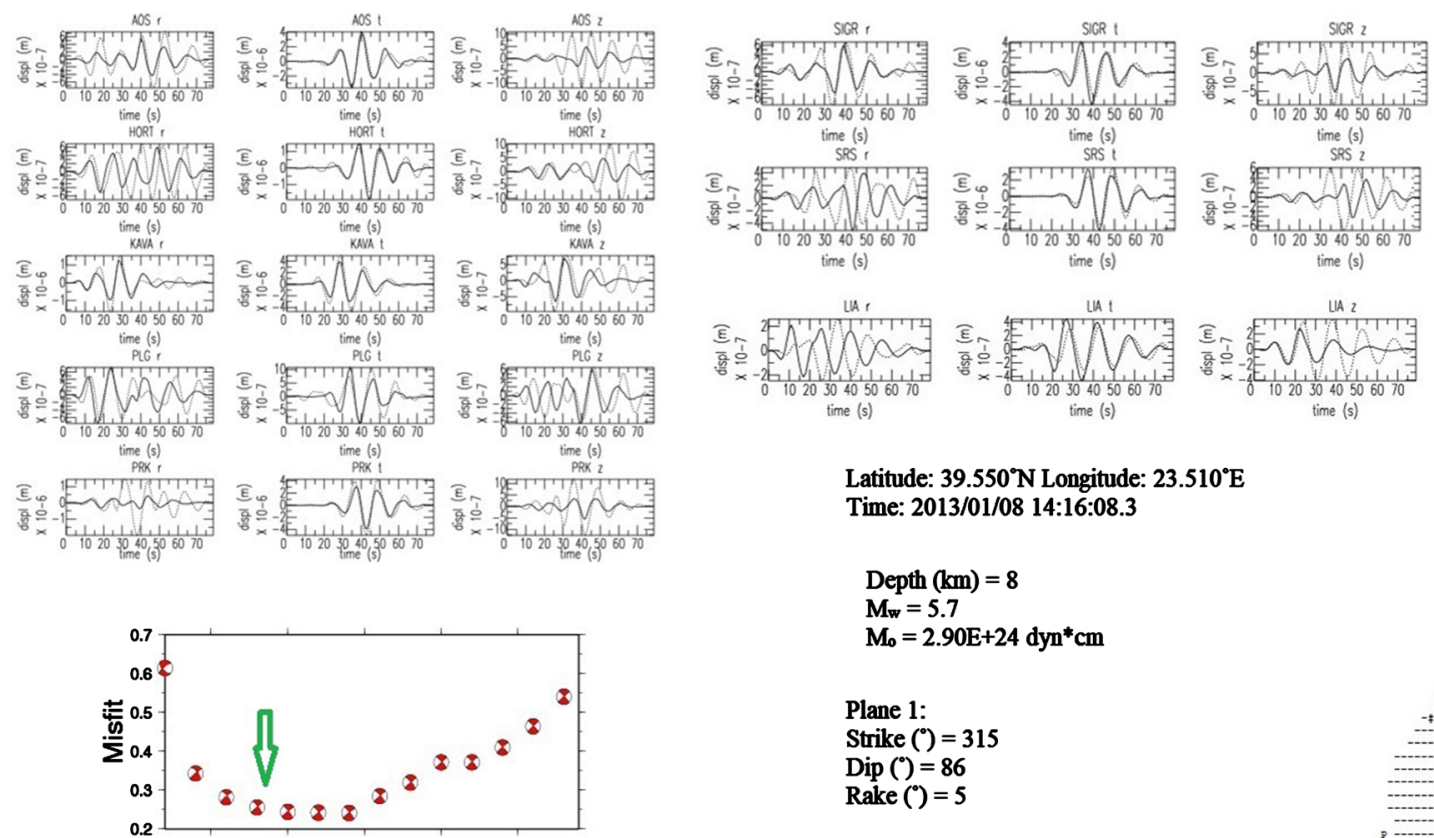

$$
\begin{aligned}
& \text { Depth }(\mathrm{km})=8 \\
& M_{\mathrm{w}}=5.7 \\
& \mathrm{M}_{0}=2.90 \mathrm{E}+24 \mathrm{dyn}^{*} \mathrm{~cm}
\end{aligned}
$$

Plane 1:

Strike $\left(^{\circ}\right)=315$

Dip $\left({ }^{\circ}\right)=86$

Rake $\left({ }^{\circ}\right)=5$

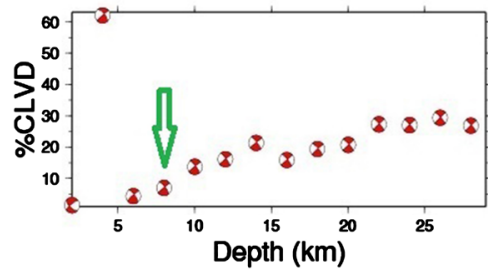

Plane 2:

Strike $\left(^{\circ}\right)=224$

Dip $\left({ }^{\circ}\right)=84$

Rake $\left(^{\circ}\right)=176$

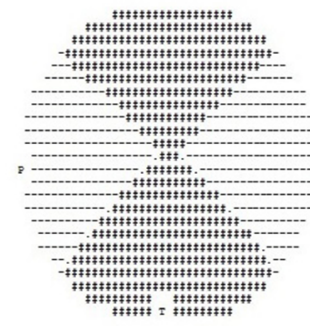

Misfit $=0.22$

$\operatorname{CLVD}(\%)=5.0$

Quality: A1

Stations Used: AOS, HORT, KAVA, PLG, PRK, SIGR, SRS, LIA

Computed by: A. Moshou

Figure 11. Moment tensor solution of the event that occurred on 8 January 2013 (14:16, UTC). Observed and synthetic displacement waveforms (continuous and dotted lines respectively) at the inverted stations for the radial, tangential and vertical components are appeared at the up section of the figure. Down of these, are presented (from left to right) the selected solution (highlighted with the green arrow) in the misfit/CLVD-versus-depth diagrams and the summary of the solution and the corresponding beach ball.

\begin{tabular}{|c|c|c|c|c|c|c|c|c|c|}
\hline Agency & Lat $\left({ }^{\circ}\right)$ & Lon $\left(^{\circ}\right)$ & Depth $(\mathrm{km})$ & Strike $1\left(^{\circ}\right)$ & $\operatorname{Dip} 1\left(^{\circ}\right)$ & Rake $1\left(^{\circ}\right)$ & Strike $2\left(^{\circ}\right)$ & $\operatorname{Dip} 2\left(^{\circ}\right)$ & Rake $2\left(^{\circ}\right)$ \\
\hline This study & 39.66 & 25.56 & 8 & 315 & 86 & -5 & 45 & 85 & -175 \\
\hline USGS & 39.70 & 25.50 & 10 & 330 & 85 & -12 & 61 & 78 & -175 \\
\hline HARVARD & 39.70 & 25.60 & 12 & 239 & 80 & 178 & 329 & 88 & 10 \\
\hline INGV & 39.70 & 25.60 & 10 & 330 & 59 & -9 & 65 & 82 & -149 \\
\hline GFZ & 39.70 & 25.60 & 13 & 331 & 77 & -1 & 61 & 89 & -167 \\
\hline UOA & 39.70 & 25.50 & 16 & 331 & 78 & -5 & 62 & 85 & -168 \\
\hline AUTH & 39.70 & 25.50 & 6 & 329 & 84 & -1 & 59 & 89 & -174 \\
\hline
\end{tabular}

Table 7. Hypocenter position (manually locations) and Focal Mechanisms by various agencies http://www.emsc-csem.org/Earthquake/tensors.php?id = 300037\&id2 = MVT29;INGF. 

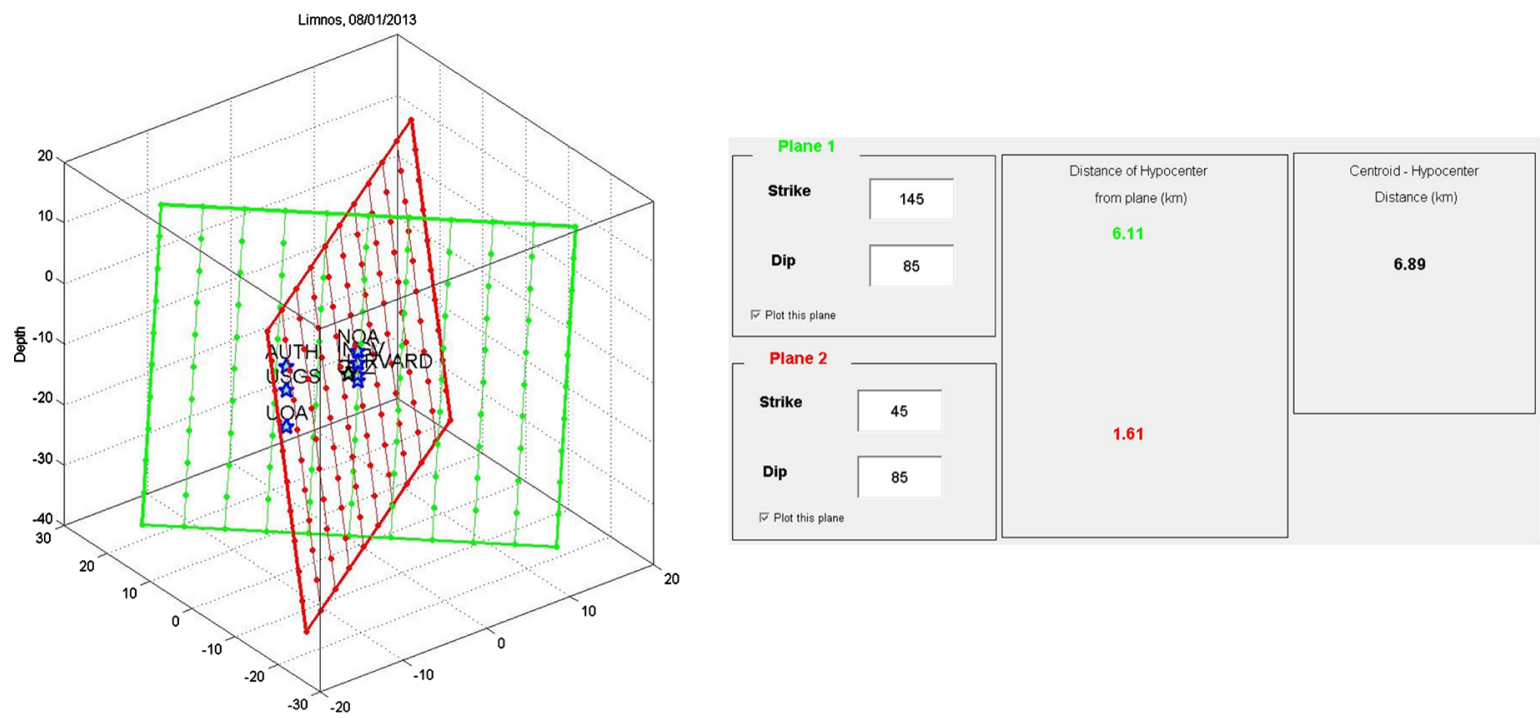

North-South (km)

East-West $(\mathrm{km})$

Figure 12. H-C Plot using the USGS, HARV, INGV, GFZ, UOA and AUTH epicenters (with varying depth), and combining it with the CMT solution of HRV, for the earthquake of January 8, 2013 Limnos island.
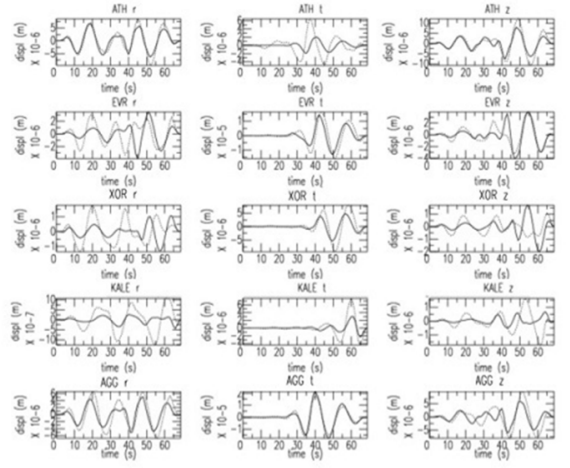
lime (s)
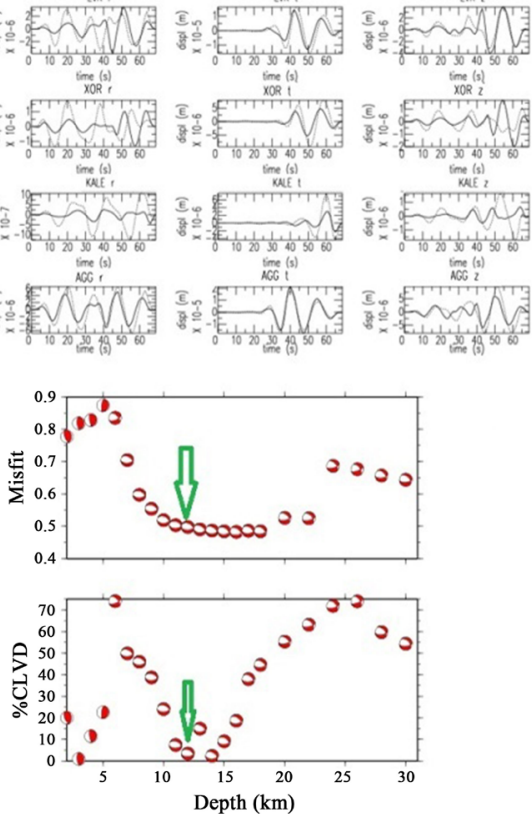

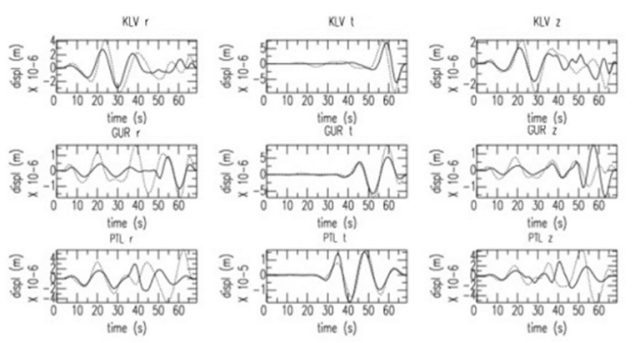

Latitude: $38.7012^{\circ} \mathrm{N}$ Longitude: $22.6950^{\circ} \mathrm{E}$

Time: $2013 / 08 / 07$ 09:06:50.3

$$
\begin{aligned}
& \text { Depth }(\mathrm{km})=12 \\
& M_{w}=5.4 \\
& M_{0}=1.20 \mathrm{E}+24 \text { dyn*cm }
\end{aligned}
$$

Plane 1:

Strike $\left({ }^{\circ}\right)=270$

$\operatorname{Dip}\left(0^{\circ}\right)=45$

Rake $\left(^{\circ}\right)=-80$

Plane 2:

Strike $\left(^{\circ}\right)=76$

$\operatorname{Dip}\left({ }^{\circ}\right)=46$

Rake $\left(^{\circ}\right)=-100$

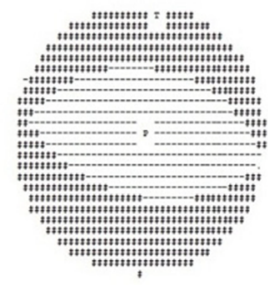

Misfit $=0.48$

CLVD $(\%)=4.0$

Quality: A1

Stations Used: ATH, EVR, XOR, KALE, AGG, KLV, GUR, PTL

Computed bv: A. Moshou

Figure 13. Moment tensor solution of the event that occurred on 7 August 2013 (09:30, UTC). Observed and synthetic displacement waveforms (continuous and dotted lines respectively) at the inverted stations for the radial, tangential and vertical components. Down of these, are presented (from left to right) the selected solution is highlighted with the green arrow in the misfit/CLVD-versus-depth diagrams and the summary of the solution and the corresponding beach ball. 


\subsection{The $M_{w}=5.4,2013$ Kalidromo Mountain Earthquake, Central Greece}

On August 7, 2013 (09:06, UTC) a moderate earthquake, Mw $=5.4$ occurred in central Kallidromon Mountain, in the Pthiotis region of central Greece. The event was manually located at $38.7012^{\circ} \mathrm{N}, 22.6950^{\circ} \mathrm{E}$, and the depth calculated at $8 \mathrm{~km}$, using recordings of the HUS Network. Four minutes before at 09:02, (UTC) a foreshock of $\mathrm{M}_{\mathrm{w}}=4.3$ has occurred. For the next three months, eleven aftershocks with $\mathrm{M}_{\mathrm{L}}=4.0$ happened in the same area with the largest of these on September 16, 2013 (15:01, UTC) with $M_{w}=5.3$. For the same time interval, 2270 aftershocks $\left(1<\mathrm{M}_{\mathrm{L}}<5.2\right)$ were recorded and relocated [22]. The moment tensor solutions for events with magnitudes, $\mathrm{M}_{\mathrm{w}} \geq 3.7$, were calculated and presented in the following table (Table 8).

Table 8. Moment Tensors Solutions for 24 studied events $\left(M_{w} \geq 3.7\right)$ of the Kalidromo Sequence (07/08/2013-07/11/2013). Columns (from left to right) show: event number, date and origin time, latitude and longitude of the epicenter, seismic moment, moment magnitude, the depth of the location and the depth as it calculated by the moment tensor inversion, strike dip and rake of the two nodal planes.

\begin{tabular}{|c|c|c|c|c|c|c|c|c|c|c|c|c|c|}
\hline \multirow[b]{2}{*}{$\mathrm{N} / \mathrm{N}$} & \multicolumn{2}{|c|}{ Origin Time } & \multicolumn{2}{|c|}{ Location } & \multicolumn{2}{|c|}{ Magnitude } & \multirow[b]{2}{*}{$\mathbf{M}_{\mathrm{w}}$} & \multicolumn{3}{|c|}{ Nodal Plane 1} & \multicolumn{3}{|c|}{ Nodal Plane 2} \\
\hline & $\begin{array}{c}\text { Date } \\
(\mathrm{D} / \mathrm{M} / \mathrm{Y})\end{array}$ & $\begin{array}{l}\text { Time } \\
\text { (UTC) }\end{array}$ & $\begin{array}{l}\text { Lat } \\
\left({ }^{\circ}\right)\end{array}$ & $\begin{array}{l}\text { Lon } \\
\left({ }^{\circ}\right)\end{array}$ & $\begin{array}{c}M_{0} \\
\left(\text { dyn }{ }^{*} \mathrm{~cm}\right)\end{array}$ & $\begin{array}{c}\text { Depth } \\
(\mathrm{km})\end{array}$ & & $\begin{array}{c}\text { Strike } \\
\left({ }^{\circ}\right)\end{array}$ & $\begin{array}{l}\text { Dip } \\
\left({ }^{\circ}\right)\end{array}$ & $\begin{array}{c}\text { Rake } \\
\left({ }^{\circ}\right)\end{array}$ & $\begin{array}{c}\text { Strike } \\
\left(^{\circ}\right)\end{array}$ & $\begin{array}{l}\text { Dip } \\
\left({ }^{\circ}\right)\end{array}$ & $\begin{array}{c}\text { Rake } \\
\left({ }^{\circ}\right)\end{array}$ \\
\hline 1 & $07 / 08 / 2013$ & 09:02:45 & 38.7030 & 22.6676 & $2.76 \mathrm{E}+22$ & 4.3 & 14.1 & 15 & 252 & 27 & -87 & 69 & 63 \\
\hline 2 & $07 / 08 / 2013$ & $09: 17: 35$ & 38.6857 & 22.6984 & $3.88 \mathrm{E}+21$ & 3.7 & 11.3 & 9 & 275 & 35 & -82 & 85 & 55 \\
\hline 3 & 07/08/2013 & 09:18:13 & 38.6980 & 22.6926 & $3.88 \mathrm{E}+21$ & 3.7 & 11.2 & 9 & 257 & 42 & -86 & 72 & 48 \\
\hline 4 & 07/08/2013 & 09:51:51 & 38.6863 & 22.662 & $3.88 \mathrm{E}+21$ & 3.7 & 12.9 & 7 & 265 & 45 & -90 & 85 & 45 \\
\hline 5 & $07 / 08 / 2013$ & 09:56:35 & 38.7013 & 22.695 & $1.84 \mathrm{E}+21$ & 4.1 & 13.6 & 10 & 278 & 41 & -86 & 93 & 49 \\
\hline 6 & $07 / 08 / 2013$ & $10: 02: 33$ & 38.6817 & 22.685 & $3.88 \mathrm{E}+21$ & 3.7 & 18.1 & 8 & 265 & 30 & -87 & 82 & 60 \\
\hline 7 & 07/08/2013 & $13: 44: 32$ & 38.6908 & 22.690 & $1.15 \mathrm{E}+23$ & 4.7 & 15.0 & 8 & 255 & 25 & -80 & 64 & 65 \\
\hline 8 & 07/08/2013 & $14: 36: 11$ & 38.6862 & 22.683 & $3.88 \mathrm{E}+21$ & 3.7 & 11.4 & 11 & 267 & 27 & -97 & 95 & 63 \\
\hline 9 & $07 / 08 / 2013$ & $16: 03: 44$ & 38.6863 & 22.647 & $3.88 \mathrm{E}+21$ & 3.7 & 10.5 & 7 & 271 & 45 & -89 & 90 & 45 \\
\hline 10 & $08 / 08 / 2013$ & $16: 35: 31$ & 38.7102 & 22.683 & $3.88 \mathrm{E}+21$ & 3.7 & 11.3 & 10 & 258 & 41 & -88 & 75 & 49 \\
\hline 11 & 09/08/2013 & $11: 49: 23$ & 38.7010 & 22.772 & $1.50 \mathrm{E}+23$ & 4.8 & 18.6 & 8 & 260 & 55 & -100 & 97 & 36 \\
\hline 12 & 09/08/2013 & 11:49:56 & 38.6937 & 22.677 & $1.00 \mathrm{E}+23$ & 4.5 & 9.40 & 8 & 262 & 30 & -86 & 77 & 60 \\
\hline 13 & $09 / 08 / 2013$ & 13:10:10 & 38.6915 & 22.647 & $1.50 \mathrm{E}+23$ & 4.7 & 16.6 & 13 & 300 & 30 & -30 & 57 & 76 \\
\hline 14 & $09 / 08 / 2013$ & $13: 43: 44$ & 38.6768 & 22.625 & $7.01 \mathrm{E}+21$ & 3.8 & 10.3 & 9 & 275 & 32 & -79 & 82 & 59 \\
\hline 15 & $14 / 08 / 2013$ & $17: 12: 57$ & 38.6995 & 22.667 & $4.87 \mathrm{E}+21$ & 3.8 & 19.5 & 8 & 245 & 30 & -88 & 63 & 60 \\
\hline 16 & $18 / 08 / 2013$ & $10: 42: 54$ & 38.7018 & 22.762 & $7.01 \mathrm{E}+21$ & 3.8 & 13.5 & 10 & 250 & 45 & -87 & 66 & 45 \\
\hline 17 & $18 / 08 / 2013$ & $16: 39: 21$ & 38.7033 & 22.797 & $8.10 \mathrm{E}+21$ & 3.9 & 13.2 & 9 & 262 & 36 & -89 & 81 & 54 \\
\hline 18 & $18 / 08 / 2013$ & $22: 16: 19$ & 38.7090 & 22.678 & $4.87 \mathrm{E}+21$ & 3.8 & 10.3 & 11 & 268 & 26 & -96 & 95 & 64 \\
\hline 19 & $16 / 09 / 2013$ & $14: 42: 39$ & 38.7000 & 22.768 & $1.04 \mathrm{E}+23$ & 4,6 & 19.6 & 10 & 270 & 25 & -93 & 93 & 65 \\
\hline 20 & $16 / 09 / 2013$ & 15:01:14 & 38.7188 & 22.753 & $8.66 \mathrm{E}+23$ & 5.3 & 17.4 & 7 & 272 & 30 & -90 & 92 & 60 \\
\hline 21 & $16 / 09 / 2013$ & $15: 15: 46$ & 38.7118 & 22.790 & $3.88 \mathrm{E}+21$ & 3.7 & 12.5 & 8 & 275 & 29 & -86 & 90 & 61 \\
\hline 22 & $16 / 09 / 2013$ & $16: 13: 09$ & 38.7082 & 22.718 & $2.94 \mathrm{E}+21$ & 3.6 & 12.4 & 9 & 265 & 35 & -87 & 81 & 55 \\
\hline 23 & $17 / 09 / 2013$ & $05: 46: 52$ & 38.7210 & 22.730 & $7.01 \mathrm{E}+21$ & 3.8 & 17.1 & 9 & 258 & 35 & -85 & 72 & 55 \\
\hline 24 & $17 / 09 / 2013$ & $07: 39: 44$ & 38.7015 & 22.777 & $1.84 \mathrm{E}+21$ & 4.1 & 12.6 & 11 & 256 & 26 & -105 & 93 & 65 \\
\hline
\end{tabular}


Regional waveforms at epicentral distances less than $3^{\circ}$ were used to determine the source parameters of the main event as well as all the aftershocks.

The inversion indicated the activation of a normal fault for all the studied events with a variation of the dip value between $30^{\circ}$ and $40^{\circ}$ and a focal depth varied between 8 - $13 \mathrm{~km}$. For the first event (August, 72013 - 09:06 UTC) the regional data from 8 stations with good azimuthally coverage was used. The source parameters as they calculated applying the moment tensor inversion method found: strike $=270^{\circ}, \operatorname{dip}=45^{\circ}$, rake $=-80^{\circ}$ the seismic moment $\mathrm{M}_{0}=1.2$ $\times 10^{24} \mathrm{dyn} \cdot \mathrm{cm}$ for a depth of $12 \mathrm{~km}$. The calculated double couple was found equal to $96 \%$, while the compensated linear vector dipole (CLVD) to $4 \%$. The results of the applied procedure are presented in Figure 13.

To apply the HC-plot method, the followed 5 hypocenter manually locations (Table 9) were considered (Figure 14).

The previous solutions were considered: HRV, INGV, GFZ, AUTH and NOA. All these solutions are characterized by similar strike-dip-rake angles, with one nodal plane, strike $265^{\circ}$, dip $50^{\circ}$, plotted in green and hereafter referred to as the "green" plane and the other one dipping, strike $75^{\circ}$, dip $50^{\circ}$, as the "red" plane.

\subsection{The $M_{w}=6.1,2014$ Kefallinia Earthquake}

On January 26, 2014 (13:55, UTC) two strong earthquakes of magnitude $\mathrm{M}_{\mathrm{w}}=$ 6.1 and $\mathrm{M}_{\mathrm{w}}=5.2(18: 45$, UTC) occurred on the island of Kefallinia, Ionia Sea. These events inducing extensive structural damages, mainly in the western and central parts. Eight days later on February 3, 2014 (03:08, UTC) a second strong event with a magnitude similar to the first $\left(\mathrm{M}_{\mathrm{w}}=6.0\right)$ happened at the north section of Lixouri town. These two earthquakes $\left(\mathrm{M}_{\mathrm{w}}=6.1\right.$ and $\left.\mathrm{M}_{\mathrm{w}}=6.0\right)$ occurred in the same island as the destructive events of 1953. Between August $9^{\text {th }}$ and 12 th of 1953, three earthquakes of magnitude 6.4, 6.8 and 7.2 took place in Cephalonia leading to hundreds of casualties and strong damages all over the island, but also in Zante and Ithaca.

These events were followed by a serious number of aftershocks. We noted that

Table 9. Hypocenter position (manually locations) and focal mechanisms by various agencies, http://www.emsc-csem.org/Earthquake/tensors.php?id = 328948\&id2 = OUE35;HARV.

\begin{tabular}{ccccccccccc}
\hline Agency & Lat $\left(^{\circ}\right)$ & Lon $\left(^{\circ}\right)$ & Depth $(\mathrm{km})$ & Strike 1 $\left(^{\circ}\right)$ & Dip 1 $\left(^{\circ}\right)$ & Rake 1 $\left(^{\circ}\right)$ & Strike 2 $\left(^{\circ}\right)$ & Dip 2 $\left(^{\circ}\right)$ & Rake 2 $\left.^{\circ}\right)$ \\
\hline This study & 39.66 & 25.56 & 8 & 315 & 86 & -5 & 45 & 85 & -175 \\
USGS & 39.70 & 25.50 & 10 & 330 & 85 & -12 & 61 & 78 & -175 \\
HARVARD & 39.70 & 25.60 & 12 & 239 & 80 & 178 & 329 & 88 & 10 \\
INGV & 39.70 & 25.60 & 10 & 330 & 59 & -9 & 65 & 82 & -149 \\
GFZ & 39.70 & 25.60 & 13 & 331 & 77 & -1 & 61 & 89 & -167 \\
UOA & 39.70 & 25.50 & 16 & 331 & 78 & -5 & 62 & 85 & -168 \\
AUTH & 39.70 & 25.50 & 6 & 329 & 84 & -1 & 59 & 89 & -174 \\
\hline
\end{tabular}



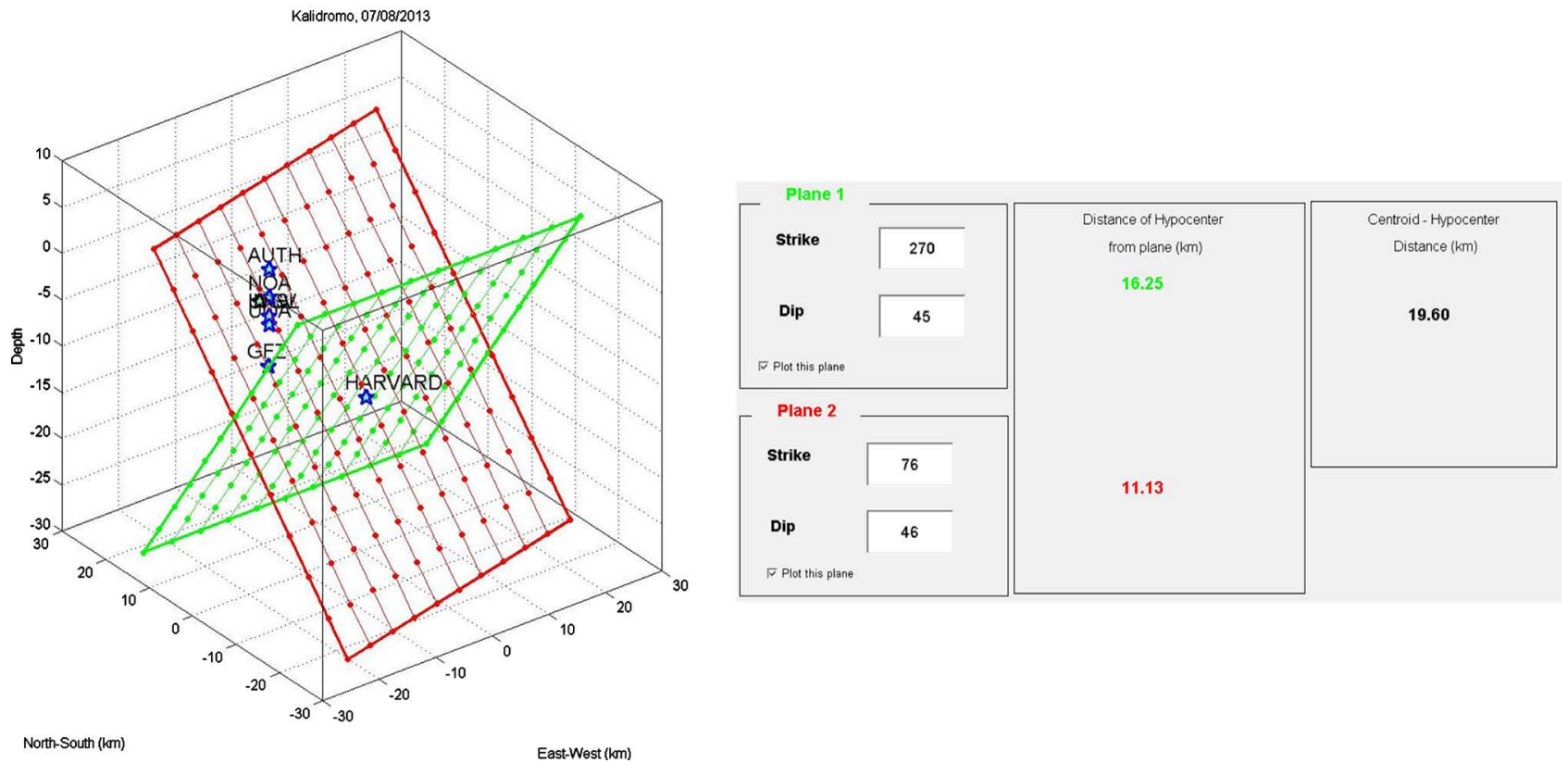

Figure 14. Nodal planes 1 and 2 are shown in red and green, respectively. Centroid is in the middle of the intersection of the nodal planes. The hypocenter solutions of USGS, HARVARD, INGV, GFZ, AUTH and NOA are representing with blue triangle.

two months after the main event was recorded and analyzed more than 4000 events. The three large earthquakes, as well as all the aftershocks were relocated [1] [22] [23]. The source parameters for the strongest of these earthquakes $\left(M_{w} \geq 4.0\right)$ were calculated, using the moment tensor inversion and presented in Table 10.

Follow, we will present the focal mechanism for January 26, 2013 (13:55, UTC) earthquake, $M_{w}=6.1$ (Figure 15). The data of 6 stations at regional data in epicentral distances less than $370 \mathrm{~km}$ were used and inverted, as it appeared in Figure 10. The inversion indicated the activation of a strike-slip faulting with source parameters strike $=23^{\circ}$, dip $=68^{\circ}$, rake $=175^{\circ}$ the depth calculated at 13 $\mathrm{km}$ and the moment magnitude $\mathrm{M}_{0}=1.51 \times 10^{25} \mathrm{dyn} \cdot \mathrm{cm}$. The fit between observed and synthetic waveforms and the misfit/CLVD versus depth diagram presented in Figure 15.

Six hypocenters manually locations were considered from NOA, HARV, GFZ, INGV, UOA and AUTH (Table 11).

The following CMT solutions were considered: HRV, GFZ, INGV, AUTH, UOA and NOA (Figure 16). All these solutions are characterized by similar strike-dip-rake angles, with one nodal plane, strike $20^{\circ}$, dip $70^{\circ}$, plotted in green and hereafter referred to as the "green" plane and the other one, with strike $130^{\circ}$, $\operatorname{dip} \sim 80^{\circ}$, as the "red" plane.

The distance of the hypocenter from this plane is $3.46 \mathrm{~km}$, while the distance from the other plane is $3.87 \mathrm{~km}$. The distance between Hypocenter and Centroid is $8.05 \mathrm{~km}$ (Figure 17). A preliminary result, about the activation of the main fault, is this with source parameters: strike $=23^{\circ}$, dip $=68^{\circ}$ and rake $=175^{\circ}$. As it appears in Figure 16 the distance between the plane and the Hypocenter-Centroid is similar. 
Table 10. Moment Tensors Solutions for 36 studied events $\left(M_{w} \geq 4.0\right)$ of the Kefallinia Sequence (07/08/2013 - 05/03/2014). Columns (from left to right) show: event number, date and origin time, latitude and longitude of the epicenter, seismic moment, moment magnitude, the depth of the location and the depth as it calculated by the moment tensor inversion, strike dip and rake of the two nodal planes.

\begin{tabular}{|c|c|c|c|c|c|c|c|c|c|c|c|c|c|c|}
\hline \multirow[b]{2}{*}{$\mathrm{Nr}$} & \multicolumn{2}{|c|}{ Origin } & \multicolumn{2}{|c|}{ Location } & \multirow{2}{*}{$\begin{array}{c}\text { Mo } \\
(\text { dyn } \cdot \mathrm{cm})\end{array}$} & \multirow{2}{*}{$\mathrm{Mw}$} & \multicolumn{2}{|c|}{ Depth } & \multicolumn{3}{|c|}{ Plane 1} & \multicolumn{3}{|c|}{ Plane 2} \\
\hline & $\begin{array}{c}\text { Date } \\
(\mathrm{D} / \mathrm{M} / \mathrm{Y})\end{array}$ & $\begin{array}{l}\text { Time } \\
\text { (UTC) }\end{array}$ & $\begin{array}{l}\text { Lat } \\
\left({ }^{\circ}\right)\end{array}$ & $\begin{array}{l}\text { Lon } \\
\left({ }^{\circ}\right)\end{array}$ & & & Catalog & MT & $\begin{array}{c}\text { Strike } \\
\left({ }^{\circ}\right)\end{array}$ & $\begin{array}{l}\text { Dip } \\
\left({ }^{\circ}\right)\end{array}$ & $\begin{array}{c}\text { Rake } \\
\left({ }^{\circ}\right)\end{array}$ & $\begin{array}{c}\text { Strike } \\
\left({ }^{\circ}\right)\end{array}$ & $\begin{array}{l}\text { Dip } \\
\left({ }^{\circ}\right)\end{array}$ & $\begin{array}{c}\text { Rake } \\
\left({ }^{\circ}\right)\end{array}$ \\
\hline 1 & $26 / 01 / 2014$ & 14:08:39 & 38.188 & 20.5325 & $2.96 \mathrm{E}+22$ & 4.3 & 18.9 & 12 & 20 & 64 & 170 & 114 & 81 & 26 \\
\hline 2 & $26 / 01 / 2014$ & $14: 21: 58$ & 38.2088 & 20.3787 & $9.52 \mathrm{E}+21$ & 4.0 & 9.9 & 8 & 22 & 67 & 168 & 117 & 79 & 23 \\
\hline 3 & $26 / 01 / 2014$ & $14: 24: 04$ & 38.2532 & 20.3903 & $2.22 \mathrm{E}+22$ & 4.2 & 14.5 & 14 & 19 & 62 & 170 & 114 & 81 & 28 \\
\hline 4 & $26 / 01 / 2014$ & $14: 41: 39$ & 38.2167 & 20.4757 & $2.22 \mathrm{E}+22$ & 4.2 & 17.1 & 13 & 20 & 60 & 172 & 114 & 83 & 30 \\
\hline 5 & $26 / 01 / 2014$ & $14: 55: 50$ & 38.2132 & 20.4100 & $9.52 \mathrm{E}+21$ & 4.0 & 14.2 & 14 & 23 & 68 & 176 & 115 & 86 & 22 \\
\hline 6 & $26 / 01 / 2014$ & $14: 59: 25$ & 38.3030 & 20.4753 & $7.35 \mathrm{E}+22$ & 4.5 & 12.9 & 12 & 25 & 65 & 179 & 115 & 89 & 25 \\
\hline 7 & $26 / 01 / 2014$ & $15: 36: 39$ & 38.2363 & 20.4373 & $1.38 \mathrm{E}+22$ & 4.1 & 17.1 & 13 & 18 & 64 & 170 & 112 & 81 & 26 \\
\hline 8 & $26 / 01 / 2014$ & 19:03:07 & 38.1873 & 20.4177 & $2.96 \mathrm{E}+22$ & 4.3 & 17.1 & 13 & 20 & 69 & 169 & 114 & 80 & 21 \\
\hline 9 & $26 / 01 / 2014$ & $19: 12: 04$ & 38.2408 & 20.4002 & $4.06 \mathrm{E}+22$ & 4.4 & 18.0 & 12 & 22 & 70 & 168 & 116 & 79 & 20 \\
\hline 10 & $26 / 01 / 2014$ & $21: 15: 34$ & 38.1337 & 20.3002 & $8.17 \mathrm{E}+22$ & 4.6 & 10.4 & 11 & 23 & 65 & 170 & 117 & 81 & 25 \\
\hline 11 & $26 / 01 / 2014$ & $21: 42: 12$ & 38.1890 & 20.4862 & $9.52 \mathrm{E}+21$ & 4.0 & 13.0 & 13 & 17 & 64 & 165 & 114 & 77 & 27 \\
\hline 12 & $26 / 01 / 2014$ & $23: 06: 55$ & 38.2398 & 20.4297 & $2.22 \mathrm{E}+22$ & 4.2 & 18.3 & 13 & 24 & 65 & 174 & 117 & 85 & 25 \\
\hline 13 & $27 / 01 / 2014$ & 09:47:38 & 38.1517 & 20.4025 & $1.38 \mathrm{E}+22$ & 4.1 & 14.8 & 14 & 26 & 68 & 175 & 118 & 85 & 22 \\
\hline 14 & $27 / 01 / 2014$ & $13: 05: 50$ & 38.2308 & 20.4403 & $2.96 \mathrm{E}+22$ & 4.3 & 11.1 & 11 & 19 & 69 & 169 & 113 & 80 & 21 \\
\hline 15 & $27 / 01 / 2014$ & $15: 39: 34$ & 38.3748 & 20.4222 & $2.22 \mathrm{E}+22$ & 4.2 & 13.8 & 13 & 20 & 80 & -173 & 289 & 83 & -10 \\
\hline 16 & $28 / 01 / 2014$ & 01:05:55 & 38.2542 & 20.4347 & $9.52 \mathrm{E}+21$ & 4.0 & 15.1 & 12 & 20 & 65 & 172 & 113 & 83 & 25 \\
\hline 17 & $28 / 01 / 2014$ & $05: 12: 53$ & 38.2083 & 20.3817 & $2.96 \mathrm{E}+22$ & 4.3 & 12.8 & 8 & 22 & 62 & 170 & 117 & 81 & 28 \\
\hline 28 & $28 / 01 / 2014$ & 08:07:11 & 38.2138 & 20.5502 & $9.52 \mathrm{E}+21$ & 4.0 & 15.3 & 11 & 23 & 60 & 172 & 117 & 83 & 30 \\
\hline 19 & $28 / 01 / 2014$ & $14: 49: 33$ & 38.2120 & 20.4552 & $9.52 \mathrm{E}+21$ & 4.0 & 17.7 & 11 & 25 & 68 & 174 & 117 & 84 & 22 \\
\hline 20 & $28 / 01 / 2014$ & $19: 12: 11$ & 38.4048 & 20.5022 & $1.38 \mathrm{E}+22$ & 4.1 & 10.6 & 12 & 17 & 64 & 176 & 109 & 86 & 26 \\
\hline 21 & $28 / 01 / 2014$ & $22: 22: 37$ & 38.4037 & 20.4885 & $2.22 \mathrm{E}+22$ & 4.2 & 15.6 & 13 & 20 & 65 & 173 & 113 & 84 & 25 \\
\hline 22 & $28 / 01 / 2014$ & $22: 23: 39$ & 38.3927 & 20.4418 & $2.22 \mathrm{E}+22$ & 4.2 & 15.9 & 12 & 22 & 60 & 175 & 115 & 86 & 30 \\
\hline 23 & $30 / 01 / 2014$ & 11:06:18 & 38.4050 & 20.5267 & $4.06 \mathrm{E}+22$ & 4.4 & 9.2 & 8 & 4 & 73 & 159 & 100 & 70 & 18 \\
\hline 24 & $31 / 01 / 2014$ & $06: 52: 47$ & 38.4210 & 20.4843 & $4.06 \mathrm{E}+22$ & 4.4 & 12.4 & 12 & 19 & 64 & 170 & 113 & 81 & 26 \\
\hline 25 & $31 / 01 / 2014$ & $12: 45: 40$ & 38.4180 & 20.4677 & $2.96 \mathrm{E}+22$ & 4.3 & 18.6 & 13 & 18 & 65 & 170 & 112 & 81 & 25 \\
\hline 26 & $01 / 02 / 2014$ & $16: 33: 38$ & 38.1727 & 20.3876 & $7.35 \mathrm{E}+22$ & 4.5 & 10.6 & 12 & 17 & 68 & 175 & 109 & 85 & 22 \\
\hline 27 & $04 / 02 / 2014$ & $19: 42: 12$ & 38.2817 & 20.3702 & $2.22 \mathrm{E}+22$ & 4.2 & 16.5 & 11 & 23 & 66 & 172 & 116 & 83 & 24 \\
\hline 28 & $07 / 02 / 2014$ & $03: 26: 43$ & 38.3253 & 20.4325 & $2.22 \mathrm{E}+22$ & 4.2 & 13 & 9 & 25 & 60 & 170 & 120 & 81 & 30 \\
\hline 29 & $07 / 02 / 2014$ & 08:59:43 & 38.2338 & 20.4558 & $2.22 \mathrm{E}+22$ & 4.2 & 12.9 & 12 & 20 & 65 & 175 & 114 & 81 & 25 \\
\hline 30 & $09 / 02 / 2014$ & $08: 22: 58$ & 38.1752 & 20.3675 & $7.35 E+22$ & 4.5 & 11.2 & 12 & 20 & 67 & 180 & 110 & 90 & 23 \\
\hline
\end{tabular}




\section{Continued}

\begin{tabular}{|c|c|c|c|c|c|c|c|c|c|c|c|c|c|c|}
\hline 31 & $12 / 02 / 2014$ & $10: 34: 31$ & 38.1655 & 20.3538 & $8.17 \mathrm{E}+22$ & 4.6 & 11.1 & 12 & 25 & 70 & 166 & 120 & 77 & 21 \\
\hline 32 & $14 / 02 / 2014$ & $03: 38: 33$ & 38.1677 & 20.3432 & $8.17 \mathrm{E}+22$ & 4.7 & 9.8 & 13 & 20 & 67 & 170 & 114 & 81 & 23 \\
\hline 34 & $05 / 03 / 2014$ & $12: 49: 20$ & 38.078 & 20.3092 & $8.17 \mathrm{E}+22$ & 4.6 & 20.4 & 12 & 30 & 70 & 170 & 123 & 80 & 15 \\
\hline 35 & $05 / 03 / 2014$ & $15: 08: 43$ & 38.0792 & 20.3467 & $1.38 \mathrm{E}+22$ & 4.1 & 18 & 14 & 18 & 70 & 168 & 112 & 79 & 20 \\
\hline 36 & $05 / 03 / 2014$ & $18: 42: 02$ & 38.1423 & 20.4185 & $9.52 \mathrm{E}+21$ & 4.0 & 16.3 & 12 & 22 & 65 & 168 & 117 & 79 & 25 \\
\hline
\end{tabular}
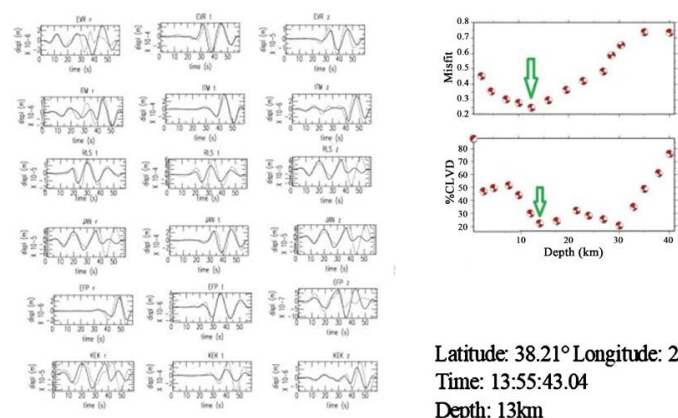

Latitude: $38.21^{\circ}$ Longitude: $21.46^{\circ}$

Time: 13:55:43.04

Depth: $13 \mathrm{~km}$

$\mathrm{M}_{\mathrm{w}}=6.1$

$\mathrm{M}_{0}=1.51 \mathrm{E} 25$

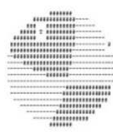

Plane 1:

Strike: $23^{\circ}$

Dip: $68^{\circ}$

Rake: $175^{\circ}$

Plane 2:

Strike: $115^{\circ}$

Dip: $82^{\circ}$

Rake: $22^{\circ}$

Misfit: 0.22

CLVD(\%): 12

Quality: A2

Stations used: EVR, ITM, RLS, JAN, EFP, KEK

Computed by: A. Moshou

Figure 15. Moment tensor solution of the event that occurred on 26 January 2014 (13:55, UTC). Observed and synthetic displacement waveforms (continuous and dotted lines respectively) at the inverted stations for the radial, tangential and vertical components. Down of these, are presented (from left to right) the selected, solution is highlighted with the green arrow, in the misfit/CLVD-versus-depth diagrams and the summary of the solution and the corresponding beach ball.

Table 11. Hypocenter position (manually locations) and focal mechanisms by various agencies, http://www.emsc-csem.org/Earthquake/tensors.php?id=357329\&id2=kr068;INFO.

\begin{tabular}{|c|c|c|c|c|c|c|c|c|c|}
\hline Agency & $\begin{array}{l}\text { Lat } \\
\left({ }^{\circ}\right)\end{array}$ & $\begin{array}{l}\text { Lon } \\
\left({ }^{\circ}\right)\end{array}$ & $\begin{array}{c}\text { Depth } \\
(\mathrm{km})\end{array}$ & $\begin{array}{c}\text { Strike } 1 \\
\left({ }^{\circ}\right)\end{array}$ & $\begin{array}{c}\text { Dip } 1 \\
\left({ }^{\circ}\right)\end{array}$ & $\begin{array}{c}\text { Rake } 1 \\
\left({ }^{\circ}\right)\end{array}$ & $\begin{array}{c}\text { Strike } 2 \\
\left({ }^{\circ}\right)\end{array}$ & $\begin{array}{c}\text { Dip } 2 \\
\left({ }^{\circ}\right)\end{array}$ & $\begin{array}{c}\text { Rake } 2 \\
\left({ }^{\circ}\right)\end{array}$ \\
\hline This study & 38.21 & 21.46 & 18 & 23 & 68 & 175 & 115 & 85 & 22 \\
\hline HRV & 38.20 & 20.40 & 12 & 12 & 45 & 154 & 120 & 72 & 48 \\
\hline GFZ & 38.20 & 20.50 & 14 & 300 & 56 & 43 & 183 & 56 & 138 \\
\hline INGV & 38.20 & 20.40 & 8 & 13 & 43 & 161 & 118 & 77 & 49 \\
\hline UOA & 38.20 & 20.50 & 16 & 35 & 62 & 175 & 124 & 80 & 20 \\
\hline AUTH & 38.20 & 20.50 & 7 & 17 & 87 & -177 & 287 & 87 & -3 \\
\hline
\end{tabular}




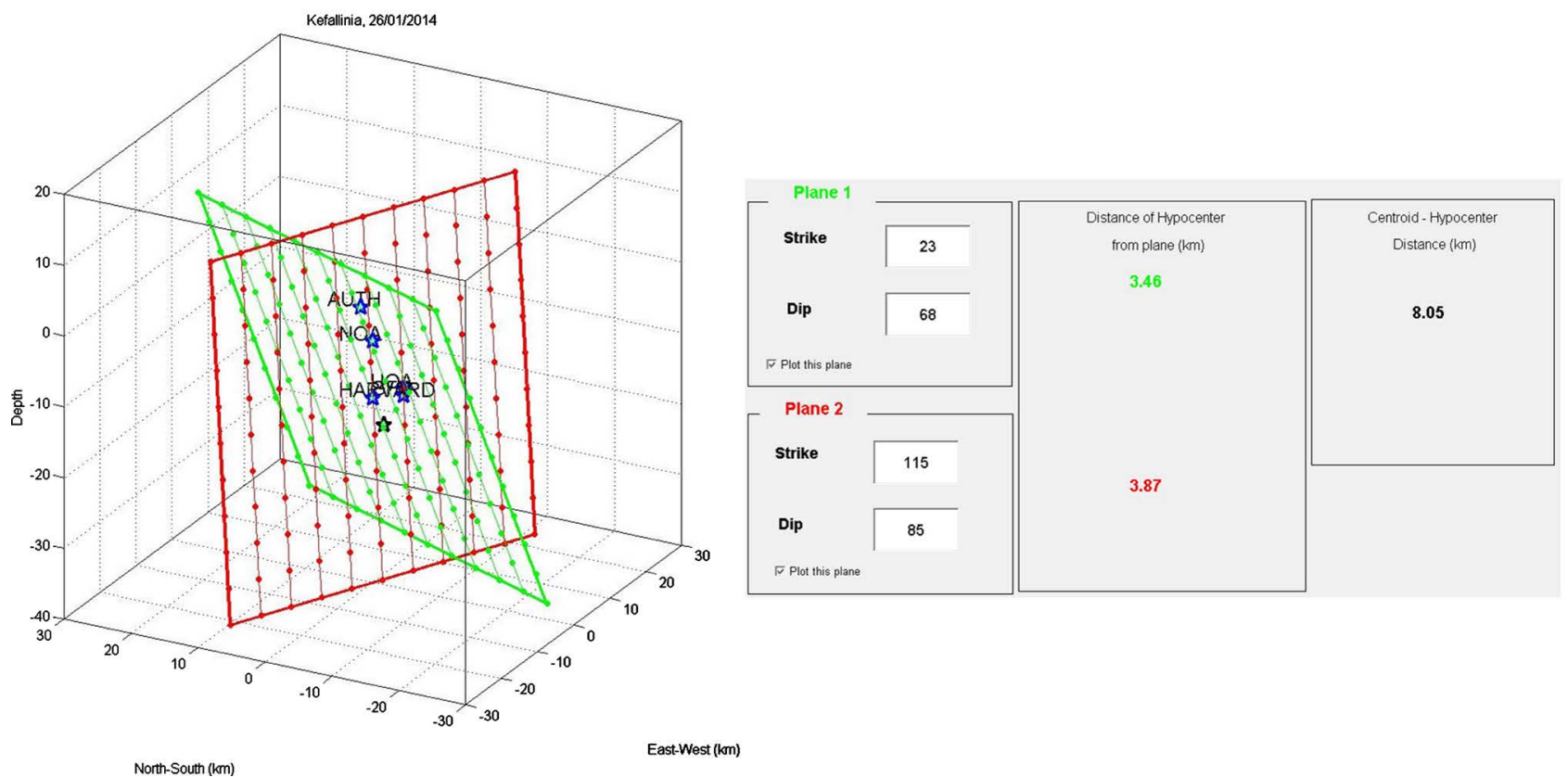

Figure 16. Nodal planes 1 and 2 are shown in red and green, respectively. The hypocenter solutions of USGS, HARVARD, INGV, ETHZ and AUTH are representing with blue triangle.

\section{Conclusions}

The knowledge of the source parameters for moderate earthquakes is very important for seismically active regions, especially in the case where no large events occur. In general, it allows analytical studies; reveals the tectonics and the seismogenic characteristics of a specific region. The methodology that was used in this study is applied to the seven largest events that occurred recently in Greece. Concerning the 2006 Kythira and the 2008 Leonidio deep events at depths equal to $69 \mathrm{~km}$ and $85 \mathrm{~km}$ respectively [24] [25]. On the other hand, the seismic parameters of the 2008 Methoni and Andravida earthquakes, the 2013 Kalidromo Mountain (Central Greece) [26] and finally the most recent event the $2014 \mathrm{Ke}$ fallinia Island were determined using the proposed methodology. For this purpose, regional data from Hellenic Unified Seismological Network, with epicentral distances less than $350 \mathrm{~km}$, were selected and analyzed. The methodology is based on the generation of synthetics seismograms using the method of Kennett [8] for given earth-structure and then they compared with the corresponding observed. The next step was the deconvolution of the instrument response from the waveforms and then their integration to produce displacement. A band-pass filter was applied both to synthetics and observed seismograms and finally horizontal components rotated to radial and transverse. For all the events with magnitude, $\mathrm{M}_{\mathrm{w}}>5.5$ that occurred in Greece at the last years the source parameters as well as the fault that re-activated was calculated and present in Table 12. With bold represent the main fault, after the text edit has been completed, the paper is ready for the template. Duplicate the template file by using the Save as command, and use the naming convention prescribed by your journal for the name 
Table 12. Earthquakes source parameters determinate in the present study, http://www.globalcmt.org/CMTsearch.html.

\begin{tabular}{|c|c|c|c|c|c|c|c|c|c|c|c|c|c|c|}
\hline \multirow{2}{*}{$\mathrm{N} / \mathrm{N}$} & \multicolumn{2}{|c|}{ Origin Time } & \multicolumn{2}{|c|}{ Location } & \multicolumn{2}{|c|}{ Magnitude } & \multirow[t]{2}{*}{$\begin{array}{c}\text { Depth } \\
(\mathrm{km})\end{array}$} & \multicolumn{3}{|c|}{ Nodal Plane 1} & \multicolumn{3}{|c|}{ Nodal Plane 2} & \multirow{2}{*}{ Institute } \\
\hline & $\begin{array}{c}\text { Date } \\
(\mathrm{D} / \mathrm{M} / \mathrm{Y})\end{array}$ & $\begin{array}{l}\text { Time } \\
\text { (UTC) }\end{array}$ & $\begin{array}{l}\text { Lat } \\
\left({ }^{\circ}\right)\end{array}$ & $\begin{array}{l}\text { Lon } \\
\left({ }^{\circ}\right)\end{array}$ & $\begin{array}{c}M_{0} \\
\left(\text { dyn }^{*} \mathrm{~cm}\right)\end{array}$ & $\mathbf{M}_{\mathrm{w}}$ & & $\begin{array}{l}\text { Strike } \\
\left({ }^{\circ}\right)\end{array}$ & $\begin{array}{l}\text { Dip } \\
\left(\left(^{\circ}\right)\right.\end{array}$ & $\begin{array}{l}\text { Rake } \\
\left({ }^{\circ}\right)\end{array}$ & $\begin{array}{l}\text { Strike } \\
\left({ }^{\circ}\right)\end{array}$ & $\begin{array}{l}\text { Dip } \\
\left({ }^{\circ}\right)\end{array}$ & $\begin{array}{l}\text { Rake } \\
\left({ }^{\circ}\right)\end{array}$ & \\
\hline \multirow[t]{2}{*}{1} & 08/01/2006 & $11: 34: 54.00$ & 36.214 & 23.406 & $8.40 \mathrm{E}+25$ & 6.40 & 69 & 205 & 48 & 59 & 67 & 50 & 120 & This study \\
\hline & & $11: 35: 00.30$ & 35.930 & 23.290 & $1.51 \mathrm{E}+26$ & 6.70 & 64 & 201 & 44 & 55 & 66 & 55 & 119 & HARVARD \\
\hline \multirow[t]{2}{*}{2} & $06 / 01 / 2008$ & 05:14:19.30 & 37.114 & 22.775 & $1.60 \mathrm{E}+25$ & 6.00 & 85 & 114 & 75 & 120 & 228 & 33 & 28 & This study \\
\hline & & 05:14:23.70 & 36.980 & 22.870 & $2.25 \mathrm{E}+25$ & 6.20 & 92 & 117 & 77 & 130 & 222 & 41 & 20 & HARVARD \\
\hline \multirow[t]{2}{*}{3} & $14 / 02 / 2008$ & 10:09:23.40 & 36.500 & 21.780 & $8.43 E+25$ & 6.60 & 29 & 290 & 16 & 69 & 132 & 75 & 96 & This study \\
\hline & & 10:09:29.00 & 36.240 & 21.790 & $2.37 \mathrm{E}+26$ & 6.80 & 20 & 332 & 6 & 120 & 121 & 85 & 87 & HARVARD \\
\hline \multirow[t]{2}{*}{4} & 08/06/2008 & $12: 25: 27.90$ & 37.980 & 21.510 & $4.49 \mathrm{E}+25$ & 6.40 & 22 & 123 & 70 & 1 & 33 & 90 & 160 & This study \\
\hline & & $12: 25: 36.90$ & 37.930 & 21.630 & $4.56 \mathrm{E}+25$ & 6.40 & 24 & 301 & 74 & 7 & 209 & 83 & 164 & HARVARD \\
\hline \multirow[t]{2}{*}{5} & $08 / 01 / 2013$ & $14: 16: 08.32$ & 39.663 & 25.562 & $3.90 \mathrm{E}+24$ & 5.70 & 8 & 315 & 86 & -5 & 224 & 84 & -176 & This study \\
\hline & & $14: 16: 11.40$ & 39.620 & 25.610 & $6.63 \mathrm{E}+24$ & 5.80 & 15 & 331 & 83 & -1 & 61 & 59 & -173 & HARVARD \\
\hline \multirow[t]{2}{*}{6} & $07 / 08 / 2013$ & 09:06:51.86 & 38.701 & 22.680 & $1.20 \mathrm{E}+24$ & 5.40 & 12 & 270 & 45 & -80 & 76 & 46 & -100 & This study \\
\hline & & 09:06:54.00 & 38.540 & 22.690 & $1.60 \mathrm{E}+24$ & 5.40 & 13 & 267 & 27 & -78 & 73 & 64 & -96 & HARVARD \\
\hline \multirow[t]{2}{*}{7} & $26 / 01 / 2014$ & $13: 55: 43.04$ & 38.219 & 20.532 & $1.51 \mathrm{E}+25$ & 6.10 & 5 & 23 & 68 & 175 & 115 & 85 & 22 & This study \\
\hline & & $13: 55: 50.40$ & 38.150 & 20.360 & $2.04 \mathrm{E}+25$ & 6.10 & 14 & 20 & 65 & 177 & 111 & 87 & 25 & HARVARD \\
\hline
\end{tabular}

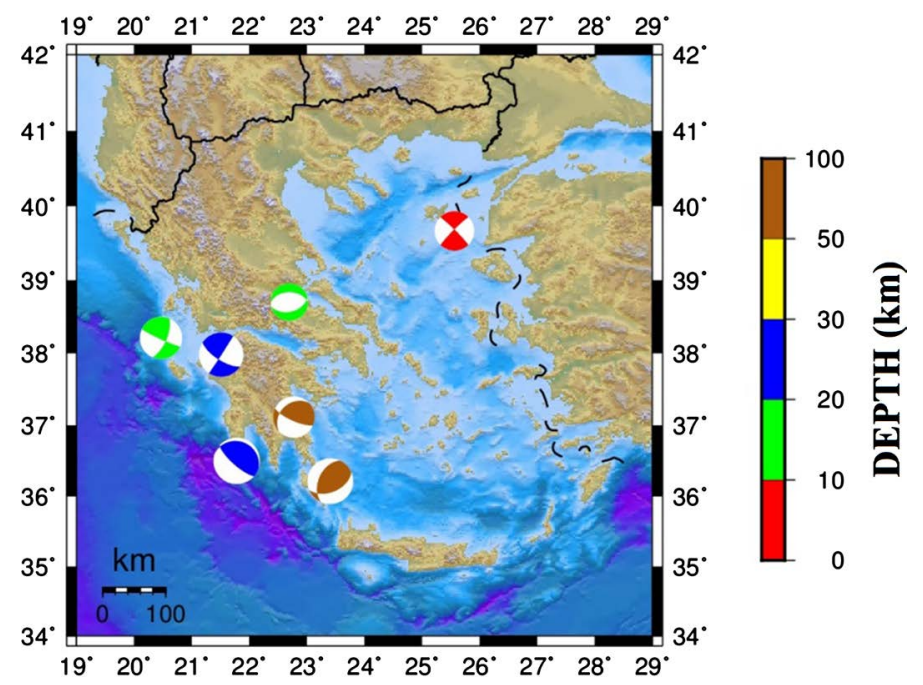

Figure 17. Focal mechanisms solutions, determined using regional data, in this study between 2006-2014.

of your paper. In this newly created file, highlight all of the contents and import your prepared text file. You are now ready to style your paper.

The method was applied for a large variety of magnitudes and could determine the fault plane orientation and the seismic moment even under conditions of poor azimuthal coverage, as the fit of data and synthetics was well predicted for most events. All the solutions were compared with those from other institutes and they were in very good agreement. The focal mechanisms solutions for the events determined in this study appear in Figure 17. 


\section{Acknowledgements}

I acknowledge the use of Hellenic Unified Seismograph Network (HUSN) data and I would like to thank the NOA scientific personnel for phase picking. The open-source software GMT http://www.soest.hawaii.edu/gmt/ was used to make several figures.

I gratefully thank the operators of the European permanent seismic networks who make their data available through EIDA, http://www.orfeus-eu.org/eida. In this study data from the following Institutes were used.

- HL (NOA, Hellenic Seismic Network), doi:10.7914/SN/HL.

- HT (Aristotle University of Thessaloniki Seismological Network), doi:10.7914/SN/HT.

- HP (University of Patras, Seismological Laboratory), doi:10.7914/SN/HP.

- HA (National and Kapodistrian University of Athens, Seismological Laboratory), doi:10.7914/SN/HA.

\section{Conflicts of Interest}

The author declares no conflicts of interest regarding the publication of this paper.

\section{References}

[1] Moshou, A. (2011) Source Parameters Determination Using Broadband Seismograms for Earthquakes in the Hellenic Region Epicentral Distances Less than $90^{\circ}$. http://hdl.handle.net/10442/hedi/26243

[2] Zahradnik, J., Sokos, E., Serpetsidaki, A. and Tselentis, G.A. (2008) The Mw 6.2 Leonidio, Southern Greece Earthquake of January 6, 2008: Preliminary Identification of the Fault Plane. http://www.emsc-csem.org/Files/event/74692/Leonidio CUP UPSL emsc.pdf

[3] Zahradnik, J., Sokos, E., Serpetsidaki, A. and Tselentis, G.A. (2008) The Mw 6.2 Le-Onidio, Southern Greece Earthquake of January 6, 2008: Preliminary Identification of the Fault Plane. Report Sent to EMSC on January 6, 2008. http://www.emsc-csem.org/Doc/20080608 GREECE/H C 0806 2008.pdf

[4] Madariaga, R. and Papadimitriou, P. (1985) Gaussian Beam Modelling of Upper Mantle Phases. Annales Geophysicae, 3, 799-812.

[5] Jost, M. and Hermann, R. (1989) A Student's Guide to and Review of Moment Tensors. Seismological Research Letters, 60, 37-57. https://doi.org/10.1785/gssrl.60.2.37

[6] Kanamori, H. (1972) Determination of Effective Tectonic Stress Associated with Earthquake Faulting, the Tottori Earthquake of 1943. Physics of the Earth and Planetary Interiors, 5, 426-434. https://doi.org/10.1016/0031-9201(72)90114-8

[7] Papadopoulos, G., Karastathis, V., Ganas, A., Pavlides, S., Fokaefs, A. and Orfanogiannaki, K. (2003) The Lefkada Ionian Sea (Greece), Shock (Mw 6.2) of 14 Augoust 2003: Evidence for the Characteristic Earthquake from Seismicity and Ground Failures. Earth Planets Space, 55, 713-718. https://doi.org/10.1186/BF03352478

[8] Kennett, B.N.L. (1983) Seismic Wave Propagation in Stratified Media. Cambridge University Press, Cambridge.

[9] Konstantinou, K.I., Melis, N.S. and Boukouras, K. (2010) Routine Regional Moment 
Tensor Inversion for Earthquakes in the Greek Region; the National Observatory of Athens (NOA) Database (2001-2006). Seismological Research Letters, 81, 750-760.

[10] Wyss, M. and Baer, M. (1981) Earthquake Hazard in the Hellenic Arc. In: Simpson, D.W. and Richards, P.G., Eds., Earthquake Prediction, Maurice Ewing Series, Vol. 4, American Geophysical Union, Washington DC, 153-172. https://doi.org/10.1029/ME004p0153

[11] Kahle, H.-G., Muller, M.V. and Veis, G. (1996) Trajectories of Crustal Deformation of Western Greece from GPS Observations 1989-1994. Geophysical Research Letters, 23, 667-680. https://doi.org/10.1029/96GL00264

[12] McClusky, S., Balassanian, S., Barka, A., Demir, C., Ergintav, S., Georgiev, I., Gurkan, O., Hamburger, M., Hurst, K., Kahle, H., Kastens, K., Kekelidze, G., King, R., Kotzev, V., Lenk, O., Mahmoud, S., Mishin, A., Nadariya, M., Ouzounis, A., Paradissis, D., Peter, Y., Prilepin, M., Reilinger, R., Sanli, I., Seeger, H., Tealeb, A., Toksoz, M.N. and Veis, G. (2000) Global Positioning System Constraints on Plate Kinematics and Dynamics in the Eastern Mediter-Ranean and Caucasus. Journal of Geophysical Research, 105, 5695-5719. https://doi.org/10.1029/1999JB900351

[13] Ganas, A., Serpelloni, E., Drakatos, G., Kolligri, M., Adamis, I., Tsimi, Ch. and Batsi, E. (2009) The Mw 6.4 SW-Achaia (Western Greece) Earthquake of 8 June 2008: Seismological, Field, GPS Observations, and Stress Modeling. Journal of Earthquake Engineering, 13, 1101-1124. https://doi.org/10.1080/13632460902933899

[14] Kalogeras, I., Melis, N. and Evangelides, C. (2013) The Earthquake of January 8, 2013 at SE of Limnos Island, Northern Aegean, Greece. NOA Online Report. http://www.gein.noa.gr/Documents/pdf/Report EN PDF.pdf

[15] Brooks, M. and Ferentinos, G. (1980) Structure and Evolution of the Sporades Basin of the North Aegean Trough, Northern Aegean Sea. Tectonophysics, 68, 15-30. https://doi.org/10.1016/0040-1951(80)90006-2

[16] Koukouvelas, I.K. and Aydin, A. (2002) Fault Structure and Related Basins of the North Aegean Sea and Its Surroundings. Tectonics, 21, 1046. https://doi.org/10.1029/2001TC901037

[17] Müller, M.D., Geiger, A., Kahle, H., Veis, G., Billiris, H., Paradissis, D. and Felekis, S. (2013) Velocity and Deformation Fields in the North Aegean Domain, Greece, and Implications for Fault Kinematics, Derived from GPS Data 1993-2009. Tectonophysics, 597-598, 34-49. https://doi.org/10.1016/j.tecto.2012.08.003

[18] Hatzfeld, D., Ziazia, M., Kementzetzidou, D., Hatzidimitriou, P., Panagiotopoulos, D., Makropoulos, K., Papadimitriou, P. and Deschamps, A. (1999) Microseismicity and Focal Mechanisms at the Western Termination of the North Anatolian Fault and Their Implications for Continental Tectonics. Geophysical Journal International, 137, 891-908. https://doi.org/10.1046/j.1365-246x.1999.00851.x

[19] Karabulut, H., Roumelioti, Z., Benetatos, C., Mutlu, A., Ozalaybey, S., Aktar, M. and Kiratzi, A. (2006) A Source Study of the 6 July 2003 (Mw 5.7) Earthquake Sequence in the Gulf of Saros (Northern Aegean Sea): Seismological Evidence for the Western Continuation of the Ganos Fault. Tectonophysics, 412, 195-216. https://doi.org/10.1016/j.tecto.2005.09.009

[20] Caputo, R., Chatzipetros, A., Pavlides, S., et al. (2012) The Greek Database of Seismogenic Sources (GreDaSS): State-of-Theart for Northern Greece. Annals of Geophysics, 55, 859-894.

[21] Ganas, A., Roumelioti, Z., Karastathis, V., Chousianitis, K., Moshou, A. and Mouzakiotis, E. (2013) The Lemnos 8 January 2013 (Mw = 5.7) Earthquake: Fault Slip, 
Aftershock Properties and Static Stress Transfer Modeling in the North Aegean Sea. Journal of Seismology, 18, 433-455. https://doi.org/10.1007/s10950-014-9418-3

[22] Ganas, A., Karastathis, V., Moshou, A., Valkaniotis, S., Mouzakiotis, E. and Papathanassiou, G. (2014) Aftershock Relocation and Frequency-Size Distribution, Stress Inversion and Seismotectonic Setting of the 7 August 2013 M = 5.4 Earthquake in Kallidromon Mountain, Central Greece. Tectonophysics, 617, 101-113. https://doi.org/10.1016/j.tecto.2014.01.022

[23] Karastathis, V.K., Papoulia, J., Di Fiore, B., Makris, J., Tsambas, A., Stampolidis, A. and Papadopoulos, G.A. (2011) Deep Structure Investigations of the Geothermal Field of the North Euboean Gulf, Greece, Using 3-D Local Earthquake Tomography and Curie Point Depth Analysis. Journal of Volcanology and Geothermal Research, 206, 106-120. https://doi.org/10.1016/j.jvolgeores.2011.06.008

[24] Moshou, A., Papadimitriou, P. and Makropoulos, K. (2007) Bulletin of the Geological Society of Greece, 37.

http://www.geophysics.geol.uoa.gr/frame en/resea/seismo en.html

[25] Moshou, A., Papadimitriou, P. and Makropoulos, K. (2010) Moment Tensor Determination Using a New Waveform Inversion Technique. Bulletin of the Geological Society of Greece, 43, 2104-2113.

http://www.geophysics.geol.uoa.gr/papers/EGE2010/Moshou EGE2010.pdf

[26] Ganas, A., Mouzakiotis, E., Moshou, A. and Karastathis, V. (2016) Left-Lateral Shear inside the North Gulf of Evia Rift, Central Greece, Evidenced by Relocated Earthquake Sequences and Moment Tensor Inversion. Tectonophysics, 682, 237-248. https://doi.org/10.1016/j.tecto.2016.05.031 